\title{
Leviathan in Business: Varieties of State Capitalism and their Implications for Economic Performance
}

\section{Citation}

Musacchio, Aldo, and Sergio G. Lazzarini. "Leviathan in Business: Varieties of State Capitalism and their Implications for Economic Performance." Harvard Business School Working Paper, No. 12-108, June 2012.

\section{Permanent link}

http://nrs.harvard.edu/urn-3:HUL.InstRepos:9056789

\section{Terms of Use}

This article was downloaded from Harvard University's DASH repository, and is made available under the terms and conditions applicable to Open Access Policy Articles, as set forth at http:// nrs.harvard.edu/urn-3:HUL.InstRepos:dash.current.terms-of-use\#OAP

\section{Share Your Story}

The Harvard community has made this article openly available.

Please share how this access benefits you. Submit a story.

Accessibility 


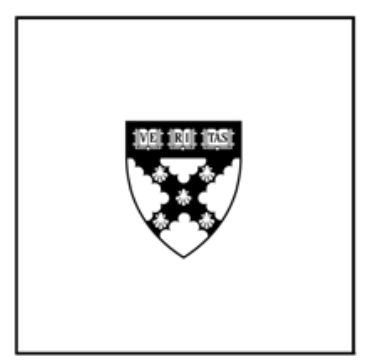

\title{
Leviathan in Business: Varieties of State Capitalism and their Implications for Economic Performance
}

\author{
Aldo Musacchio \\ Sergio G. Lazzarini
}

\section{Working Paper}

12-108

June 4, 2012 


\title{
Leviathan in Business: Varieties of State Capitalism and their Implications for Economic Performance
}

\author{
Aldo Musacchio \\ Harvard Business School and NBER \\ Soldiers Field \\ Boston, Massachusetts 02163 \\ amusacchio@hbs.edu \\ Sergio G. Lazzarini \\ Insper Institute of Education and Research \\ R. Quatá, 300 \\ São Paulo, SP Brazil 04546-042 \\ SergioGL1@insper.edu.br
}

\begin{abstract}
In this paper we document the extent and reach of state capitalism around the world and explore its economic implications. We focus on governmental provision of capital to corporations - either equity or debt - as a defining feature of state capitalism. We present a stylized distinction between two broad, general varieties of state capitalism: one through majority control of publicly traded companies (e.g. state-controlled SOEs) and a hybrid form that relies on minority investments in companies by development banks, pension funds, sovereign wealth funds, and the government itself. We label these two alternative modes Leviathan as a majority investor and Leviathan as a minority investor, respectively. Next we differentiate between these two modes by describing their key fundamental traits and the conditions that should make each mode more conducive to development and superior economic performance.
\end{abstract}

Keywords: State capitalism, state-owned enterprises, development banks, sovereign wealth funds

JEL codes: P51, L32, L33

Preliminary version for discussion

May 2012 


\section{Introduction}

After over two decades of extensive state reform and privatization, state capitalism still looms large in developed and developing countries. State-owned enterprises (SOEs), development banks, public pension funds, sovereign wealth funds, among many other vehicles of governmental capital, have taken center stage in the global economy. For example, in 2005 there was no single state-owned enterprise among the top 10 firms of the Fortune Global 100 list, which ranks companies by revenues. In 2010, there were four SOEs among the top 10: Japan Post Holdings, Sinopec and China National Petroleum (two of China's national oil companies), and State Grid (a Chinese utility). ${ }^{1}$

Many observers view these developments with apprehension. Bremmer (2010) raises concerns about what he refers to as "state capitalism" and describes it as antithetical to the ideals of liberal capitalism. It is, he wrote, "a system in which the state functions as the leading economic actor and uses markets primarily for political gain" (Bremmer, 2010, p. 5). A summit of founders and CEOs of some of the world's top companies in the world, organized by Harvard Business School, identified state capitalism and its support for "national champions" - private or state-owned firms chosen to receive government assistance-among the ten most important threats to market capitalism (Bower, Leonard, \& Paine, 2011).

${ }^{1}$ All lists taken from the Fortune Global 500 list web page, available at http://money.cnn.com/magazines/fortune/global500/, accessed on March 3, 2012. 
Governments, particularly in emerging markets, have justified the rise of such forms of hybrid capitalism as a way to solve market failures. Private companies, in contrast, see the rise of new SOEs, firms with minority government ownership, and private companies backed by loans of development banks as threats because governments may use these competitors to influence markets (e.g. dictating their pricing strategies) or provide them with privileged access to resources unavailable to private enterprises.

Whether we regard them as benign or pernicious, we know very little about those new forms of government intervention: the various institutional mechanisms by which states exercise control, why state capitalism reemerged and in which form, and its effects on both firm performance and state governance. Moreover, we lack a conceptual framework to understand state capitalism in a more nuanced and detailed way. Although in the last decades there has been a flurry of research comparing state versus private ownership (see, for a review, Megginson \& Netter, 2001), the stylized view of state ownership usually involves state majority control. More recent discussions of the mechanisms of state capitalism, on the other hand, fail to provide a consolidated theoretical framework for the varieties of state capitalism, the distinguishing traits of those various forms, and their efficiency implications.

In this paper we document the extent and reach of state capitalism around the world and explore the economic implications of these new forms of state capitalism. We define state capitalism as the widespread influence of the government in the economy, either by 
owning majority or minority equity positions in companies or through the provision of subsidized credit and/or other privileges to private companies. We present systematic, crosscountry evidence showing that the form of state capitalism prevailing in the twenty-first century is different from what we observed in the second half of the twentieth century. Then, state involvement in enterprises took the form of command economies or mixed economies in which governments owned a large number of enterprises and directly controlled the allocation of strategic resources. More recently, perhaps paradoxically, the privatization and liberalization wave of the 1980s and 1990s helped create a new form of hybrid capitalism where the government influences the investment decisions of private companies through minority capital.

Thus, we present a stylized distinction between two broad, general forms of state capitalism: through majority control (e.g. state-controlled SOEs) or in a more hybrid fashion through minority investments by development banks, pension funds, sovereign wealth funds and the government itself. To use Williamson's (1985) expression, those forms represent two alternative organizational modes to carry out business allocations where the state is present. We label these two alternative modes Leviathan as a majority investor and Leviathan as a minority investor respectively. ${ }^{2}$

The paper then reviews several theoretical perspectives that have been proposed to explain the emergence of each mode of state capitalism. Next we differentiate between the majority and minority investor model by describing their key fundamental 2012).

${ }^{2}$ See, for instance, the discussion in The Economist, special issue on state capitalism (Wooldridge, 
traits and the conditions that should make each mode more conducive to development and superior economic performance. We conclude by outlining several suggestions for future research to improve our understanding of the functioning and economic implications of the various forms of state capitalism.

\section{The State of State Capitalism around the World}

After almost three decades of privatization in developed and developing countries, state capitalism still looms large. The outcomes of those privatizations were not necessarily a general strip-down of the state's productive assets. In the end, privatizations faced intense political opposition and in specific strategic sectors governments themselves decided that it was better to keep certain companies under state control. Bortolotti and Faccio's (2009) survey of SOEs in OECD countries reveals that, despite strenuous efforts to privatize, governments were still controlling a large share of the privatized firms. Except for the capital goods sector, transportation, and utilities, the share of firms under government control did not go down between 1996 and 2000 in that set of rich countries. If at all, the privatization process seems to have been more thorough in Mexico, New Zealand, Turkey, the UK, and the US.

An OECD report (Table 1) showed the importance of SOEs in member countries, particularly those in which Leviathan acted as a minority owner (OECD, 2005). In France and Italy, the assets of SOEs represented over 25 percent of GDP, while in Finland this ratio reached 80 percent. In Korea and Turkey this figure was also around 20 percent of GDP. Moreover, OECD governments have minority positions in about 25 
percent of the companies that have the government as a shareholder (See Table 1). In

Germany, over 50 percent of the federal government's equity holdings in companies

that are considered SOEs are minority positions (and that does not include companies with less than 25 percent of government ownership). In Denmark, Finland, France, the Netherlands, Poland, the Slovak Republic, and Spain over 30 percent of the companies that are identified as state-owned have the government with a minority position only. ${ }^{3}$

Table 1. Number of State-wned Enterprises With Government Minority Positions in OECD Countries, 2005

\begin{tabular}{lccc}
\hline & Number of SOEs & Minority positions & \% of minority-owned firms \\
\hline \hline Australia & 12 & 0 & $0 \%$ \\
Austria & 78 & 21 & $27 \%$ \\
Belgium & 15 & 0 & $0 \%$ \\
Canada & 100 & 15 & $15 \%$ \\
Czech Republic & $>1,000$ & $>120$ & $12 \%$ \\
Denmark & 27 & 10 & $37 \%$ \\
Finland & 55 & 19 & $35 \%$ \\
France & 100 & 33 & $33 \%$ \\
Germany & 37 & 20 & $54 \%$ \\
Greece & 50 & 14 & $28 \%$ \\
Italy & 25 & 4 & $16 \%$ \\
Japan & 77 & $n . a$ & $n . \mathrm{a}$ \\
Korea & 30 & 4 & $13 \%$ \\
Netherlands & 44 & 16 & $36 \%$ \\
New Zealand & 34 & 3 & $9 \%$ \\
Norway & 26 & 6 & $23 \%$ \\
Poland & 1,189 & 691 & $58 \%$ \\
Slovak Rep. & 115 & 55 & $48 \%$ \\
Spain & 40 & 15 & $38 \%$ \\
Sweden & 58 & 7 & $12 \%$ \\
Turkey & 39 & n.a & n.a \\
United Kingdom & 80 & 14 & $18 \%$ \\
\hline \hline
\end{tabular}

Source: All figures are estimates by the authors using the OECD (2005). Polish data comes from Waclawik-Wejman (2005).

${ }^{3}$ OECD (OECD, 2005, p. 34). It is difficult to know how much control the government of these countries has with minority positions because in some of the privatizations these governments kept minority positions but with golden shares, i.e., shares that give the government veto power over certain decisions. For further discussion on the complications to ascertain the share of equity that belongs to a government, see Bortolotti and Faccio (2009). 
Table 2 Patterns of State Ownership in Emerging Markets, c. 2010

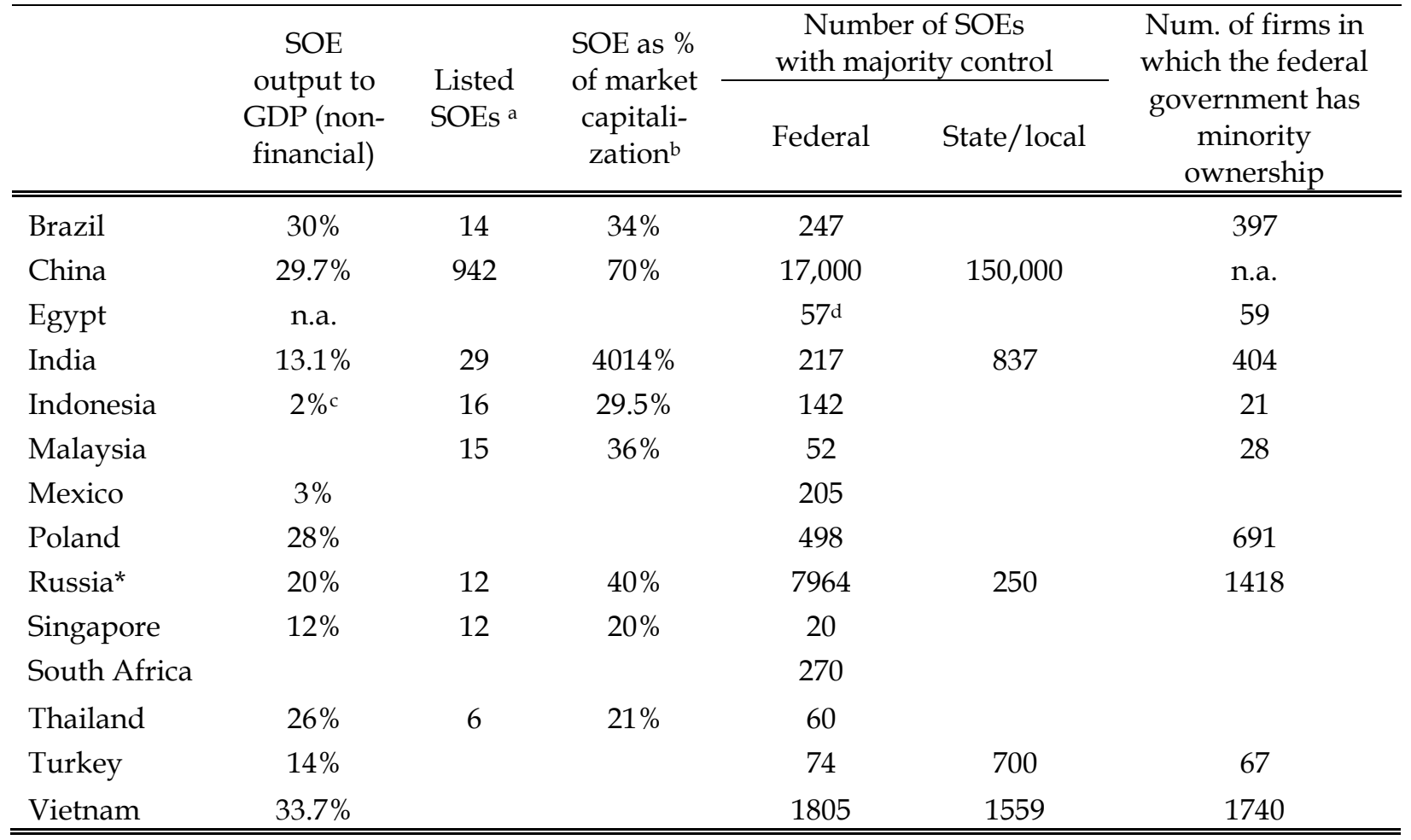

Notes: $\mathrm{a}$, b These estimates include companies under government control and those with minority ownership.

C For Indonesia this figure represents the total net profits of SOEs relative to GDP.

d For Egypt, the number of SOEs is for 2005 but the number of minority-owned firms are for 2002.

Source: See Appendix. We include all firms with government ownership of over $10 \%$ for minority shareholdings and over $50 \%$ of the votes (i.e., control) to consider it a majority-controlled SOE.

In Table 2, we see that governments of emerging markets also hold minority positions in a large set of firms. In most of the countries for which we found data, the Leviathan as a minority investor mode is prevalent and covers about 20-30 percent of the companies in which the government has equity (the rest being fully owned SOEs). This table also shows that among emerging markets, SOEs still contribute a large portion of GDP and they represent a good portion of total stock market capitalization (close to 30 percent on average). 
Figure 1 Distribution of the Number of Government Equity Holdings in Publicly traded Companies in BRIC Countries, 2007.

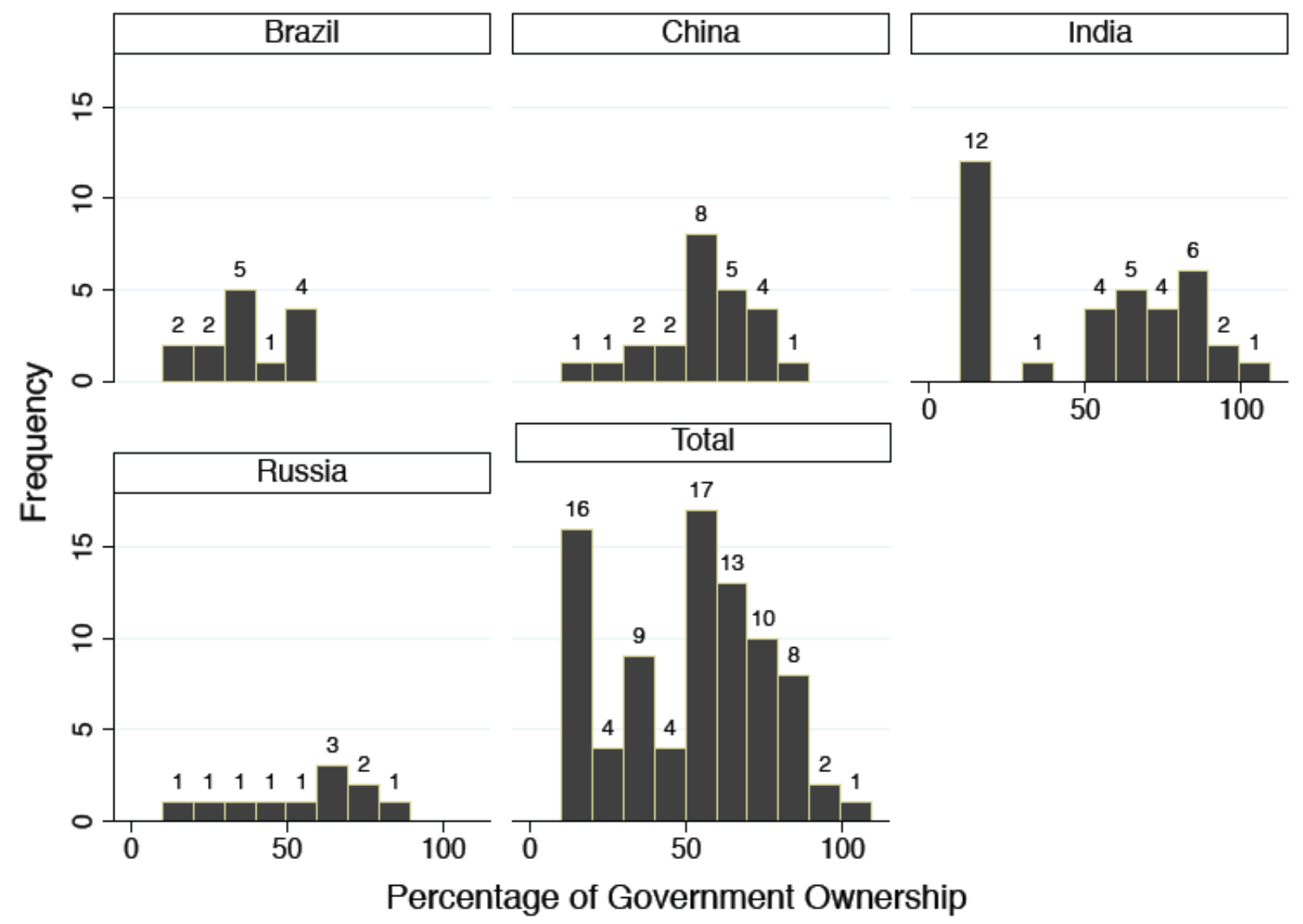

Source: Created by the authors from Capital IQ and company web pages using a sample of the largest 150 publicly traded companies in these markets.

Brazil, Russia, India, and China (BRIC), the largest emerging markets, display the same pattern of ownership we find in other parts of the emerging and developed world - that is, a mix of majority and minority ownership. In Figure 1 we show the distribution of ownership using a database of the largest 150 publicly traded companies (by market capitalization) between 2005 and 2009. Leviathan acts most often as a minority shareholder in Brazil and Russia, followed by India, where the government, or 
one of its holding companies (e.g. The Life Insurance Corp. of India), holds minority positions in a variety of firms. In China we see a greater bias towards large ownership stakes in publicly traded companies, but we still find some minority shareholdings. These minority stakes mostly occur through holding companies that are fully controlled by the government and that then invest in a variety of firm. Furthermore, as we discuss below, governments not only act as shareholders but also provide credit to firms through development banks and state-owned banks.

How can we make sense of this varied configuration of state ownership? Next we propose stylized modes of state capitalism and then discuss alternative theoretical explanations for their emergence.

\section{Modes of State Capitalism}

Economists have usually juxtaposed state capitalism and either liberal market economies or free markets in general. Ludwig von Mises, one of the most influential Austrian economists, equated state capitalism with socialism or "planned economy" (von Mises, 2009, first published in 1951). Murray N. Rothbard (1973, p. 419), a central figure in the American libertarian movement, went even further by contrasting state capitalism with free-market capitalism: "The difference between free-market capitalism and state capitalism is precisely the difference between, on the one hand, peaceful, voluntary exchange, and on the other, violent expropriation." Moreover, for Rothbard (1973), the cozying up of big business with the government was also a manifestation of state capitalism. Therefore, these two libertarian scholars equated state capitalism with 
government intervention in markets; central planning; with governments favoring big business; and even with the outright expropriation of private property.

Bremmer's (2010) provides the beginnings of a conceptual framework for understanding various degrees of state involvement in the economy. He distinguishes state capitalism from "command economies" involving planning and state-led resource allocation, and "free-market economies" featuring minimal governmental intervention (e.g. along the lines of securing property rights and establishing stable rules for private investment). He defines state capitalism as a system in which

...governments use various kinds of state-owned enterprises to manage the exploitation of resources they consider the state's crown jewels and to create and maintain large numbers of jobs. They select privately owned companies to dominate certain economic sectors. They use so-called sovereign wealth funds to invest their extra cash in ways that maximize the state's profits. In all three cases, the state is using markets to create wealth that can be directed as political officials see fit. And in all three cases the ultimate motive is not economic (maximizing growth) but political (maximizing the state's power and the leadership's chances of survival). (Bremmer, 2010; p. 4-5)

All those definitions, however, lack nuance. Bremmer, for instance, treats state capitalism as a general mode of capitalism, juxtaposed to an idealized form of liberal market economy in which the government does not intervene in the running of corporations or the allocation of credit. Consistent with Bremmer, we conceptualize state capitalism as a system where the government has a marked influence in the 
business sector. We, however, advance the extant discussion by dichotomizing state capitalism into two broader classes (Figure 2). ${ }^{4}$

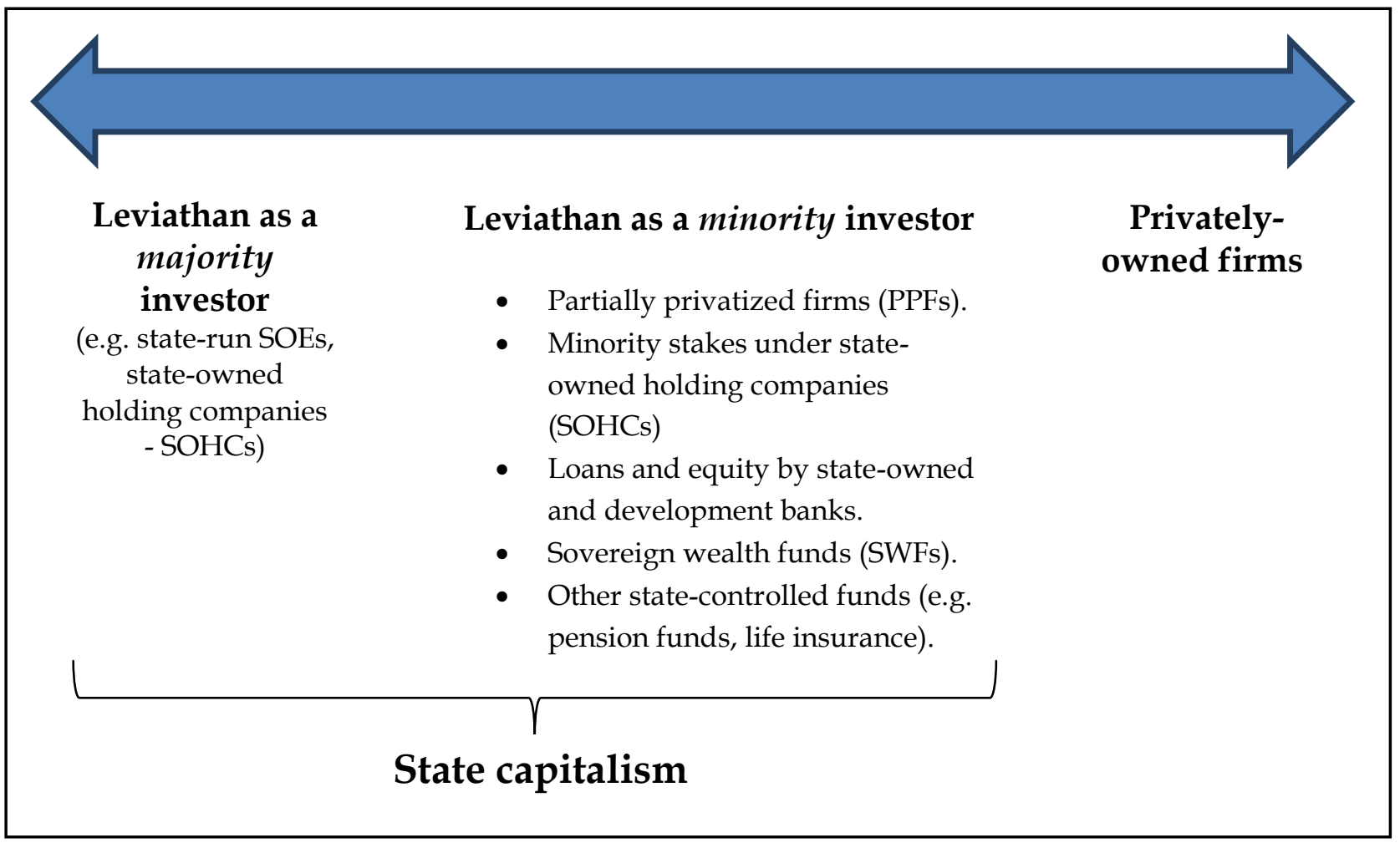

Figure 2. Varieties of State Capitalism: Alternative Modes of Organization

Closer to the more familiar view of state capitalism as a process involving outright state management, the state can act as a majority shareholder and manager of SOEs - a mode we refer to as Leviathan as a majority investor. According to Ahroni (1986), SOEs are firms in which the state has ownership and control. SOEs are also conceptualized as enterprises; that is, they should effectively produce and sell goods and services. These companies should be distinguished from government entities in charge

${ }^{4}$ Our work thus contributes to the evolving literature on the varieties of capitalism (Hall \& Soskice, 2001; Schneider \& Soskice, 2009). We however focus on state capitalism and its varied forms, which has not been studied in detail by that literature. 
of providing public services (such as courts, the police, Social Security, or National Health Services), which often do not have a corporate form and depend directly on orders from government officials.

In the Leviathan as a majority investor model, the government usually exercises control of SOEs indirectly, by appointing managers and boards of directors. In some SOEs, however, ministers act directly as presidents. Moreover, SOEs can be fully owned by the government or they can be publicly traded, as long as the government is the majority shareholder. Governments also exercise their control as a majority investor using large companies as conglomerates controlling a series of firms or through what is known as state-owned holding companies (SOHCs).

The state can also influence the economy in an indirect way, acting as a minority shareholder and lender to private firms. This is the mode we refer to as Leviathan as a minority investor. This more nuanced form of state capitalism is a hybrid form, which mixes features of full state control and private operation of enterprises. As we saw in the previous section, however, minority state participation in corporations is an increasingly worldwide phenomenon and is not uniform. We argue that there are several channels through which states exercise minority control, such as holding shares in partially privatized firms (PPFs); minority stakes under state-owned holding companies; loans and equity by state-owned and development banks; sovereign wealth funds (SWFs); and other state-controlled funds (e.g. pension funds, life insurance). We discuss each in turn. 
Leviathan as a majority investor

As is clear from Tables 1 and 2, both in developed and emerging markets governments all around the world own and control a large number of state-owned enterprises. In most cases SOEs are firms that "survived" the wave of privatization, generally in sectors deemed by governments as "strategic."

The so-called National Oil Companies (NOCs) are a typical example. NOCs are energy companies in which governments usually have either full ownership (e.g., Aramco in Saudi Arabia or Pemex in Mexico) or at least control (e.g., ENI in Italy; Statoil in Norway; Sinopec in China, Petrobras in Brazil, or Gazprom in Russia). Those firms in which governments have control but not full ownership are usually publicly traded. Some current SOEs also resulted from previously privatized companies which were subsequently "nationalized" - as is the case of Russia's state-owned gas company Gazprom.

As noted before, governments also use pyramidal structures of ownership or state-owned holding companies (SOHCs) to manage their ownership in a large number of firms. For instance, Gazprom is actually a pyramid with majority equity shares in Gazprom Neft (73.02\%), JSC "TGC-1" (51.79\%), and JSC Latvijas Gaze (53.56\%), among others. In China, the State-owned Assets Supervision and Administration Commission (SASAC) works as a holding company, overseeing over 100 additional stand-alone companies and holding companies (Lin \& Milhaupt, 2011). The government of Dubai also organizes all of the companies it controls under the umbrella of two large SOHCs: 
Dubai World and Investment Corporation of Dubai (ICD). Additionally, the ruler of Dubai, Mohammed bin Rashid had under his command Dubai Holding, another SOHC. These holding companies controlled a series of subsidiaries and two sovereign wealth funds: Dubai World controlled Istithmar World and Dubai Holding controlled Dubai International Capital.

Leviathan as a minority investor: more than what meets the eye

Because investors, analysts, companies and multilateral organizations all around the world do not fully understand the reach of Leviathan as a minority investor, usually there are surprises or misunderstandings surrounding the role governments play when they use minority investments in corporations or when they support private (and public) companies through loans from development banks and other sources of funding. We describe below the various channels through which governments can act in the minority investor mode.

Partially privatized firms (PPFs). PPFs result from particular features of privatization programs whereby governments decided to preserve a foothold in the governance of privatized companies - oftentimes with the objective to invite private management while at the same time keeping privatized firms as "national champions" influenced by governmental policies (Bremmer, 2010). Governments can, in addition, hold "golden shares" in PPFs granting special power to veto certain decisions. PPFs are also observed in cases where governments helped acquirers with state-backed equity, or converted previous loans into minority shares to rescue failing privatized firms. 
Minority stakes under state-owned holding companies (SOHCs). In other cases governments also create "pyramidal" SOHCs to handle minority stakes in various sectors. That is, holding companies operate as portfolio managers for the government. For instance, in emerging markets examples of this range from Khazanah Nasional Berhad in Malaysia to SASAC in China. Malaysia is an extreme case in terms of consolidating the management of state equity under the umbrella of one big holding company. In 2010, Khazanah Nasional Berhad owned stock in 52 companies, out of which it held minority positions in about 26 of them, in sectors ranging from financials, transportation, and utilities. ${ }^{5}$

Loans and equity by state-owned banks and development banks. Because those banks have been used extensively as sources of long-term capital to private firms (Armendáriz de Aghion, 1999), it is natural that they will have a role in the governance of those firms. Although the liberalization and privatization reforms of the 1990s reduced the scope of development banks in some countries, in several cases banks were preserved and even strengthened. Lazzarini, Musacchio, Bandeira-de-Mello and Marcon (2012) identified 286 development banks throughout the world as of 2011, chiefly concentrated in South and East Asia (29.7\%), Africa (24.5\%), and Latin America and the Caribbean (17.8\%) (Table 3). With the global financial crisis of 2008, even in the United States there have been calls to create a development bank supporting large infrastructure projects.

${ }^{5}$ All of the data for Khazanah comes from the 2010 annual report, available at http://www.khazanah.com.my/, accessed on January 10, 2012. 
Table 3. Number of Development Banks around the World (2011)

\begin{tabular}{|c|c|c|c|c|c|}
\hline & $\begin{array}{c}\text { Development } \\
\text { agencies } \\
\text { (A) }\end{array}$ & $\begin{array}{c}\text { General } \\
\text { develop- } \\
\text { ment banks } \\
\text { (B) } \\
\end{array}$ & $\begin{array}{c}\text { Special- } \\
\text { purpose } \\
\text { development } \\
\text { banks } \\
(\mathrm{C}) \\
\end{array}$ & $\begin{array}{l}\text { Commercial } \\
\text { banks with } \\
\text { development } \\
\text { objectives } \\
\text { (D) }\end{array}$ & $\begin{array}{c}\text { Total, } \\
\text { by } \\
\text { region } \\
(\mathrm{E}) \\
\end{array}$ \\
\hline Africa & 3 & 26 & 21 & 20 & 70 \\
\hline North America & & & 1 & & 1 \\
\hline South and East Asia & 13 & 23 & 22 & 27 & 85 \\
\hline Eurasia & & 8 & 2 & 9 & 19 \\
\hline Europe & & 7 & 3 & 2 & 12 \\
\hline Latin America/ Caribbean & 4 & 29 & 17 & 1 & 51 \\
\hline Middle East & & 1 & 3 & 3 & 7 \\
\hline Oceania & 1 & 5 & 5 & 4 & 15 \\
\hline Regional/Global & & 20 & 5 & 3 & 28 \\
\hline Total, by type & 21 & 119 & 79 & 69 & 288 \\
\hline
\end{tabular}

Source: Lazzarini, Musacchio, Bandeira-de-Mello and Marcon (2012). Note on the classification scheme:

A. Development agencies: includes investment authorities, training centers, and organizations that provide technical assistance to specific sectors, but that do not specialize in giving out loans.

B. General development banks are those focused on providing loans for or investing in the equity of industrial and/or infrastructure projects. It includes also banks that provide guarantees so that industrial or infrastructure projects can get private funding. They can be regional, such as the Inter-American Development Bank, or domestic, such as the Korea Development Bank.

C. Special-purpose development banks are those financial institutions specialized on credits to agriculture, small and medium enterprises, or the construction industry. That is, we include banks that want to promote construction and housing developments for families who could not get mortgage loans from regular banks. This category can include agricultural banks like The Principal Bank for Development and Agricultural Credit, from Egypt or The Land Bank of the Philippines, or banks with broader objectives such as the National Housing Bank of India.

D. There are many banks that we classify as commercial banks with some development objectives because these banks, public or private, operate as regular banks, but tend to have one part of their portfolio focused on specific sectors that the government is targeting. Examples of this are Azerigazbank in Azerbaijan, the Banco de Desarrollo Productivo in Bolivia, and the Bhutan National Bank Ltd, in Bhutan.

For instance, Brazil's development bank (BNDES) not only acts a lender, but also as a minority shareholder through a specialized private investment arm, BNDESPAR.

The role of BNDES as a conduit of state influence, jointly with other local public investors such as pension funds of SOEs, is clearly illustrated by Vale, the third largest mining company in the world. When in 2009 President Luis Inacio Lula da Silva publicly pressured Vale to invest in local steel mills and buy Brazilian ships, investors were confused. Vale was supposed to be a private company and yet the Brazilian government was acting as if it was a utility or a SOE under its control. In reality, Vale was partly privatized in 1997 when a consortium headed by private owners, BNDES, 
and pension funds bought Vale's controlling shares and created a controlling entity, Valepar. Although BNDES and the pension funds individually had minority stakes, if they voted in block they had more than $50 \%$ of controlling shares. After much public debate and after taking a lot of criticism and pressure from the Brazilian government, Vale's private shareholders eventually acquiesced and, in April of 2011, the board of directors dismissed its CEO, Roger Agnelli.

Sovereign wealth funds (SWFs). With the rapid dissemination of SWFs as an alternative way to channel country savings into investments with higher return and risk, minority shareholding positions in publicly listed companies have increasingly become targets for those funds. The majority of the investments of these funds, however, are done outside the home country because the idea is to precisely keep a pool of savings in foreign currency-denominated assets. In particular, many sovereign wealth funds are designed to diversify the investment of national foreign exchange reserves into assets other than US or European government bonds.

Some of these SWFs also invest in companies in their home countries. China Investment Corporation (CIC) buys shares (minority positions) in China's companies and banks. Temasek, Singapore's SWF invests 32\% of their portfolio locally, in companies such as Singapore Technologies Telemedia, Singapore Communications, Singapore Power, Singapore Airlines, and others. ${ }^{6}$ Mubadala, a sovereign wealth fund from Abu Dhabi, invests heavily in large development projects at home in energy,

${ }^{6}$ Data from http://www.temasekreview.com.sg/portfolio/major_companies.html, accessed on May 17, 2012. 
telecommunications, health care and other sectors. ${ }^{7}$ The Abu Dhabi Invesment Authority, one of the largest SWF's in the world, in contrast, does not invest in its home country, the United Arab Emirates.

Table 4. Largest Sovereign Wealth Funds by Assets under Management (AUM)

\begin{tabular}{lc}
\hline Fund & $\begin{array}{c}\text { AUM in } \\
\text { US\$ billions }\end{array}$ \\
\hline \hline Government Pension Fund - Global (Norway) & 431 \\
Abu Dhabi Investment Authority (UAE) & 395 \\
China Investment Corporation (China) & 332 \\
Kuwait Investment Authority (Kuwait) & 295 \\
Gov. of Singapore Investment Corporation (Singapore) & 185 \\
Temasek Holdings (Singapore) & 133 \\
National Wealth Fund (Russia) & 87 \\
Qatar Investment Authority (Qatar ) & 70 \\
Libyan Investment Authority (Libya ) & 64 \\
\hline Source: Musacchio and Staykov (2011), Exhibit 2.
\end{tabular}

Other state-controlled funds (e.g. pension funds, life insurance). In India, the Life Insurance Corporation (LIC) plays the role of large holding company for the government. LIC is the largest active stock market investor in India, with around \$50 billion invested as of September 2011. The government controls LIC and selects its board and management teams. It often directs LIC to invest in the shares of SOEs, especially when demand in the IPO of these firms is low. However, LIC and the government have also been seen to disagree publicly on some occasions. Our computations indicate that, through LIC, the government of India, as of 2012, invested 2012.

\footnotetext{
${ }^{7}$ Information from Mubadala's web page, http://mubadala.ae/portfolio/, accessed on May 17,
} 
in about 25 companies, mostly in minority stakes, which represent about $4 \%$ of the total stock market capitalization of the country. LIC is usually a passive investor. Yet, when the government directs it to buy shares in partial privatizations, those investments underperform the market in a significant way. ${ }^{8}$

In Brazil, pension funds of SOEs, whose management is influenced by governments, have minority shareholding positions in several publicly traded firms and often behave as active investors influencing the strategy of firms and even fostering mergers of firms in which they have common stakes (Lazzarini, 2011) - as is illustrated by the case of Vale, discussed earlier.

In sum, all these examples indicate that this more hybrid form of state capitalism occurs in cases where governments provide capital to private enterprises while at the same time relinquishing majority control. In all of the institutional forms described above, influence by the government, if any, is more indirect. Governments can participate in coalitions of owners ("control blocks") to influence the governance of firms; or they can allocate loans or equity conditional on firms pursuing certain desirable state objectives. ${ }^{9}$ We next present alternative explanations for the existence of those various forms of state capitalism and then more directly contrast their particular

${ }^{8}$ This is based on an analysis of the investments LIC made in the privatization (divestments) of NPC, NMDC, SJVN, Engineers India, Power Grid Corporation, the Shipping Corporation of India, PTC India Financial Services, and ONGC. LIC had a cumulative loss of 24\% in this investments by April 2012 (Vaidyanathan \& Musacchio, 2012).

${ }_{9}^{9}$ This hybrid mode of state capitalism should also be distinguished from hybrid public-private partnerships crafted to execute specific infrastructure projects or public services such as water supply, transport, prisons, and so on (Bennett \& Iossa, 2006; Cabral, Lazzarini, \& Azevedo, 2010). In our conception of hybrid state capitalism - Leviathan as a minority investor -, governments participate in corporations that can expand into several sectors instead of being focused on a particular public domain. 
traits and conditions that should make each form more conducive to superior economic performance.

\section{Why Does State Capitalism Exist?}

Several explanations have been advanced to account for the emergence of state capitalism. While some arguments take a more benign stance - i.e., governmental involvement in the economy helps solve market failures (the industrial policy view) or pursue societal objectives that diverge from pure profit-maximizing goals (the social view) - other arguments adopt a more negative view by emphasizing the distortions brought by political interference through governmental capital (the political view). Still other authors interpret the propagation and resilience of state capitalism in a more neutral fashion, as a result of complex historical processes and inherited institutional conditions (the path dependence view). We next discuss each of these views in detail.

\section{Industrial policy view}

The industrial policy view sees the provision of state capital as an important tool for solving market failures leading to suboptimal productive investment. Two major sources of market failure are commonly identified. The first has to do with capital markets. In poorly developed financial markets, investment is severely constrained (Levine, 2005), especially when firms need to undertake large-scale projects with long maturity. Governments can thus act as lenders or venture capitalists in conditions where private sources of capital are scarce. Indeed, a large literature on development 
banking proposes that state-owned banks can alleviate credit constraints in the private sector and promote projects with positive net present value that might otherwise not be undertaken (Bruck, 1998; Yeyati, Micco, \& Panizza, 2004). Moreover, in economies with significant capital constraints, governmental funding can alleviate capital scarcity and promote entrepreneurial action to boost new or existing industries (Armendáriz de Aghion, 1999; Cameron, 1961; Gerschenkron, 1962).

The second source of market failure involves coordination problems. Thus, governmental involvement may alter the nature and path of productive investments, especially when a given regional context is subject to externalities across industries and activities (Krugman, 1993; Marshall, 1920). Investing in a processing plant, for instance, will be more attractive for private owners if raw materials and efficient transportation infrastructure are available at low cost. Hirschman (1958) famously proposed that backward and forward linkages in the production chain will have to be created to spur local development. Following this logic, a "big push" by the government may be necessary to promote coordinated, complementary investments (Murphy, Shleifer, and Vishny, 1989; Rosenstein-Rodan, 1943).

Such coordination problems will be magnified in a context of shallow capital markets: were private capital abundant, governments could simply incentivize the emergence of new sectors through differential tax regimes or temporary protection. However, under conditions of capital scarcity, direct or indirect provision of state capital may be beneficial to foster complementary investments. In his in-depth analysis 
of Brazilian industrialization, Trebat (1983) concludes that SOEs were instrumental to industry-level development in a context of scarce capital markets: "Public enterprise has been considered in Brazil as a shortcut to industrialization - an expediency forced upon policymakers by the absence of a well-financed domestic private sector and by Brazil's reluctance to allow transnational corporations into certain strategic sectors" (p. 116).

Yet this discussion fails to account for the many and varied institutional forms of state capitalism. Governments may boost complementary investments by creating SOEs (with majority control) in multiple sectors. However, they may also relinquish control to private firms and provide equity through development banks or state funds. Still in other cases, private firms themselves may create alliances to spur joint investment and access foreign capital and resources through global production chains (Coe, Dicken, \& Hess, 2008; Pack \& Saggi, 2006). In other words, although the industrial policy view helps explain the role of state capitalism in addressing market failure, it does not explain why in some cases Leviathan is a majority investor, while in others Leviathan acts more indirectly through non-controlling shares or targeted lending, i.e., as a minority investor.

\section{Social view}

The social view asserts that state-influenced firms pursue a "double bottom line." That is, they will have "noncommercial" objectives that go beyond profitability or even contradict the simple principle of shareholder value maximization (Ahroni, 1986; Bai \& Xu, 2005; Shapiro \& Willig, 1990; Toninelli, 2000). In the words of Shirley and Nellis 
(1991, p. 17), "noncommercial objectives include the use of public enterprises to promote regional development, job creation, and income redistribution; they often involve taking on or maintaining redundant workers, pricing goods and services below market (sometimes even below costs), locating plants in uneconomic areas, or keeping uneconomic facilities open." Governments may also determine the cost of inputs, set wage ceilings, subsidize interest rates, or give SOEs investment funds at preferential interest rates. Thus, according to the social view, corporations controlled by the state will emerge as a way to pursue social objectives in corporate decision-making - such as high employment or low prices - by reducing the pressure to maximize profits.

Similarly, this freedom from shareholder value maximization means that state capital can pursue long-term goals that may be unpalatable to private investors seeking quicker returns (Kaldor, 1980). Private investors may reduce their shareholdings or even exit the firm in case of unsatisfactory short-term performance. Some projects, however, may deliver effective results only in the long-term, and a more "patient" source of capital may be necessary to withstand periods of market turbulence. Governments can therefore act as "a financial partner" committed to supporting valuable projects with relatively long timelines (McDermott, 2003, p. 22). Musacchio and Staykov (2011), for instance, argue that a key feature of SWFs is their long-term, patient orientation. These funds, the authors argue, "are also more immune to 'animal spirits' and could more easily withstand market panic..." In addition, "without any short-term pressure to return a significant portion of assets in cash to their 
governments, SWFs could afford to stay in their investments during market troughs" (p. 7).

Therefore, in the social view, state capitalism will deliberately attenuate the highpowered profit-based incentives of private capitalism. A reduced emphasis on profit maximization in the public sector is aligned with Williamson's (1999) analysis of public versus private governance. He introduces the concept of probity: the need for "loyalty and rectitude" (p. 322) in various domains such as "foreign affairs, the military, foreign intelligence, managing the money supply, and, possibly, the judiciary" (p. 321). Williamson (1999) argues that low-powered incentives in the public sector guarantee probity by avoiding excessive "resource deployment from cost savings" (p. 325). In similar vein, Hart, Shleifer, and Vishny (1997) stress that public organization will be desirable when profit-maximization causes an excessive emphasis on cost reduction at the expense of "quality" (e.g. effective student learning in schools). Although Williamson (1999) and Hart et al. (1997) do not focus on the state ownership of corporations, their propositions are consistent with the social view. In this sense, state capitalism may emerge as a way to "tame" the profit-based, short-term motivations of markets.

Like the industrial policy view, however, the social view does not explicitly account for the variation in state capitalism discussed earlier. Arguably, governments will more easily prompt managers to pursue social goals if they have majority controli.e. if they can veto decisions that conflict with their desired objective to avoid excessive 
unemployment or high prices. However, it is also possible that, through minority stakes, governments will be able to have some degree of influence. The long-term orientation of SWFs, discussed before, is an example. Governments may also try to convince other owners of PPFs to follow social objectives, and those owners may acquiesce to governmental interference as a way to preserve their interests in PPFs or receive future benefits (e.g. continued provision of state capital). We will further elaborate on this issue in the subsequent discussion.

\section{Political view}

While the industrial policy and social views see governmental influence and the attenuation of high-powered market incentives as benign or even beneficial, the political view underscores their resulting inefficiencies (Chong \& Lopez-de-Silanes, 2005; La Porta \& López-de-Silanes, 1999; Shleifer, 1998; Shleifer \& Vishny, 1994). Thus, Shleifer and Vishny $(1998$, p. 10) contend, "the key problem of state firms is government interference in their activities to direct them to pursue political rather than economic goals." Politicians and politically connected capitalists may extend their "grabbing hand" to divert public resources for their own benefit, with negative consequences for corporate performance. Political interference in SOEs can result in excessive employment or the selection of employees on the basis of political connections instead of merit or background, and those employees will typically lack the high-powered incentive contracts commonly found in private corporations (e.g. bonuses or stock options). Thus, SOEs that suffer from too much political intervention may end up 
making poor choices in product mix and location. They may fail to cut costs and streamline their operations in periods of crisis, and they may pursue inefficient, unprofitable investments to placate the pressure of governments.

This problem is aggravated by the so-called soft budget constraints of state corporations (Kornai, 1979; Lin \& Tan, 1999). With abundant and "patient" capital from the state, bureaucrats will be more likely to approve bad investments, and use public funds to cover existing losses or rescue failed projects. Lacking the pressure of market investors towards profitability, SOEs can be more effectively used as sources of cheap capital to meet the political objectives of governments and politicians. The political view diverges from the social view in regarding the low-powered market incentives of public governance as a critical downside. The resulting inefficiencies will be more acute depending on the extent to which political meddling distorts corporate decisionmaking.

Although political interference is arguably more intense in SOEs with majority state control, the political view also explains certain types of interference that may occur when Leviathan is a minority investor, i.e., in the hybrid mode of state capitalism. Namely, public-private connections may be conduits of cronyism: a mechanism through which "those close to the political authorities who make and enforce policies receive favors that have large economic value" (Haber, 2002, p. xii). In the political view, governments provide capital to firms not to channel funds to socially efficient uses, but 
rather to maximize their personal objectives or engage in crony deals with rent-seeking, politically-connected industrialists (e.g. Faccio, 2006; Kang, 2002; Krueger, 1990).

A recent literature has found empirical evidence consistent with the hypothesis that financing can be influenced by political factors such as election cycles and campaign donations (e.g. Claessens, Feijen, \& Laeven, 2008; Dinç, 2005; Sapienza, 2004). The implication is that governments provide capital to firms in return for political support-either through campaign donations to the government's political coalition, or investment decisions that benefit politicians and their constituencies. And firms may request subsidized credit or cheap (minority) equity even in cases where projects could be normally funded and launched using private sources of capital. The potential for cronyism also arises in the creation of "national champions" (Falck, Gollier, \& Woessmann, 2011). That is, politicians and officials explicitly pick certain private firms to receive funds, either debt or equity, as a way to propel them to consolidate their sectors and grow. On the one hand, the creation of national champions is consistent with the more benign industrial policy view asserting that state capital can solve market failures thwarting industrial development. On the other hand, some argue that the criteria governments use to select particular firms over others are not clear and have sometimes been linked to political objectives (Ades \& Di Tella, 1997). National champions may therefore be another manifestation of governments' desire to influence the private sector to pay political dividends (Bremmer, 2010). 
Consistent with this political view and our earlier discussion on PPFs, several authors submit that some governmental influence remains even after firms are privatized. Bortolloti and Faccio (2009) find that, after 2000, governments of OECD countries kept some degree of control in $62.4 \%$ of their privatized companies. Examining privatization events in transition economies, Pistor and Turkewitz (1996) observe that while private companies with state ownership ties benefit from "stategranted insurance" (p. 217), "the presence of the state as an owner has given it some leverage in influencing certain decisions, such as energy prices or the closure of factories in regions with high employment" (p. 231). Bennedsen (2000) offers a gametheoretic mode where one of the equilibria involves private capitalists acquiescing to state directives (e.g. avoiding excessive layoffs) in return for subsidies. The implications of post-privatization business-government ties are also examined by Boyko, Shleifer and Vishny (1996) and Kauffman and Siegelbaum (1996).

Therefore, while political interference may explain the desire to create SOEs, it also helps explain the emergence of hybrid (minority) state capitalism. Outright political influence through governmental fiat power is substituted for a more indirect and nuanced influence, often through crony ties. In the words of Shleifer and Vishny (1994, p. 998), "there is no magic line that separates firms from politicians once they are privatized." 10

${ }^{10}$ Focusing on the Chinese case, Nee and Oppen (2007) describe what they call "politicized capitalism," characterized by complex interactions between governments and private actors. However, while the authors see politicized capitalism as a situation of "disequilibrium" (p. 96), we submit that 
Path dependence view

The path dependence view explains both the emergence of - and variation in state capitalism as a result of idiosyncratic, country-level institutional features and historical processes. At a fundamental level, path-dependent processes occur because of complex interactions among political and economic actors who will try to preserve their interests in the face of imminent change (North, 1990). The defining event in the recent evolution of state capitalism has been the privatization programs of the last few decades of the twentieth century. Most countries around the world followed a common path in the ascent of state capitalism in earlier decades, but the process of privatization and divestiture of government-owned corporations has been uneven. The result is considerable variation in the way the state owns companies and intervenes to prop up private companies (i.e., national champions). Many aspects of the path dependence view are consistent with the political view, which emphasizes the mutual benefits that government and business actors derive from their continued connections with one another. However, while the latter underscores the inefficiencies of state capitalism, path dependence theorists tend to take a more neutral perspective, highlighting how state capitalism may simply be a manifestation of country-level persistence of certain fundamental institutions and complex social interactions. ${ }^{11}$

political exchanges have been at the realm of the hybrid state capitalism, which has been a more or less stable form in several countries.

11 For good surveys of the history and resilience of SOEs as central features of the capitalist system of Western European countries, see Toninelli (2000) and Millward (2005). In the chapters of Toninelli (2000) there are detailed histories of the rise and fall of SOEs in Italy, Germany, France, Spain, Britain, the Netherlands, and the United States. For a review of state presence in Brazil since the 
Stark's $(1994,1996)$ examination of market transition in East European countries is an example of uneven and incomplete privatization. Compiling data from newly privatized firms in Hungary, Stark (1996) reveals that they remained partially owned by state actors (Hungary's State Property Agency and the State Holding Corporation), and that these actors also participated in numerous top Hungarian firms jointly with private and foreign owners. He notes that "ironically, the agencies responsible for privatization are acting as agents of étatization" (p. 1001). He refers to this process as a recombination of public and private resources drawing on existing routines, practices, and social ties in the economy. Given that these "local" features tend to be country-specific, this view suggests not only that ownership relations will be heterogeneous across countries, but that the importance of the state will great vary according to inherited conditions (e.g. Bebchuk \& Roe, 1999). “A new social order," writes Stark (1994, p. 65), "cannot be created by dictation - at least not where citizen themselves want a voice in determining the new institutions."

A related argument is that the feasibility of privatization will depend on local ideology and attitudes towards public or private ownership (Durant \& Legge Jr., 2002; Hirschman, 1982); and that governments will try to take those considerations into account when designing reform policies. Anticipating negative public reactions associated with privatization programs, governments may involve domestic owners

nineteenth century see Musacchio (2009) and for the specific case of railways see Duncan (1932). Also consistent with path dependence, some authors have explained ownership patterns according to the legal origin of the country (La Porta, Lopez-de-Silanes, Shleifer, \& Vishny, 1998). However, these authors do not discuss state ownership in detail. 
and state agencies in the execution of those programs, while at the same time infusing state capital in the newly privatized companies as a way to signal to the public that the government remains present in the economy (Kuczynski, 1999). Negative public reactions against privatization can be especially acute when SOEs are sold to large capitalists and foreign owners. For instance, in line with Stark's (1996) findings, the Brazilian Development Bank (BNDES) not only coordinated the whole privatization program, but also kept minority stakes in several companies (Inoue, Lazzarini, \& Musacchio, 2012; Lazzarini, 2011). De Paula, Ferraz and Iooty (2002, p. 482) argue that mixed consortia involving foreign, private, and state actors in Brazil helped to "dilute political criticisms that often accompany the transfer of privatized assets to foreign entities."

Bortolotti, Fantini and Siniscalco (2004) also emphasize heterogeneity in the extent to which governments privatized SOEs, measured as total privatization revenues to GDP for 1977-1999. They find that privatization varied across countries according to three factors. First, they find that the fiscal situation of the government, when the privatization programs started, determined the urgency to privatize SOEs. Second, the level of financial market development (measured as market capitalization to GDP and the stock market turnover ratio) also determined the feasibility of mass privatization programs as it facilitated share issue privatizations. Third, these authors find that authoritarian governments have a harder time privatizing. ${ }^{12}$ Thus, local political

\footnotetext{
${ }^{12}$ It is not clear that this result holds for developing countries, where nondemocratic governments carried out some of the most thorough privatization programs. Moreover, recent evidence
} 
regimes - which tend to be very resilient - also seem to determine the extent of governmental ownership.

In sum, the path dependence view offers new insights on the prevalence of Leviathan as a majority investor and, perhaps more importantly, on the emergence of the hybrid mode of state capitalism with Leviathan as a minority investor. In the path dependence view, hybrid state capitalism will naturally result from existing rules, ties, and ideologies that existed prior to reform programs. With the transfer of assets to private owners, the state may remain partially disseminated in the economy as a way to preserve previous connections with the productive sector or to minimize public opposition towards reforms. Viewed from a different angle, a lower incidence of state capitalism may also be explained by a favorable ideological position by political parties towards more liberal markets, as is the case of Mexico or Chile (see e.g. Bremmer, 2010, p. 122).

Figure 3 shows that state capitalism does have strong path dependence, even after decades of privatization. In this figure we plot the percentage of SOE output to GDP for a series of countries that were classified as mixed economies in 1980 (such as Germany, France, and Brazil) and economies that were considered command economies (such as China, the Czech Republic, and Russia). It is clear that in more recent years, SOEs are still more important in former command economies. 


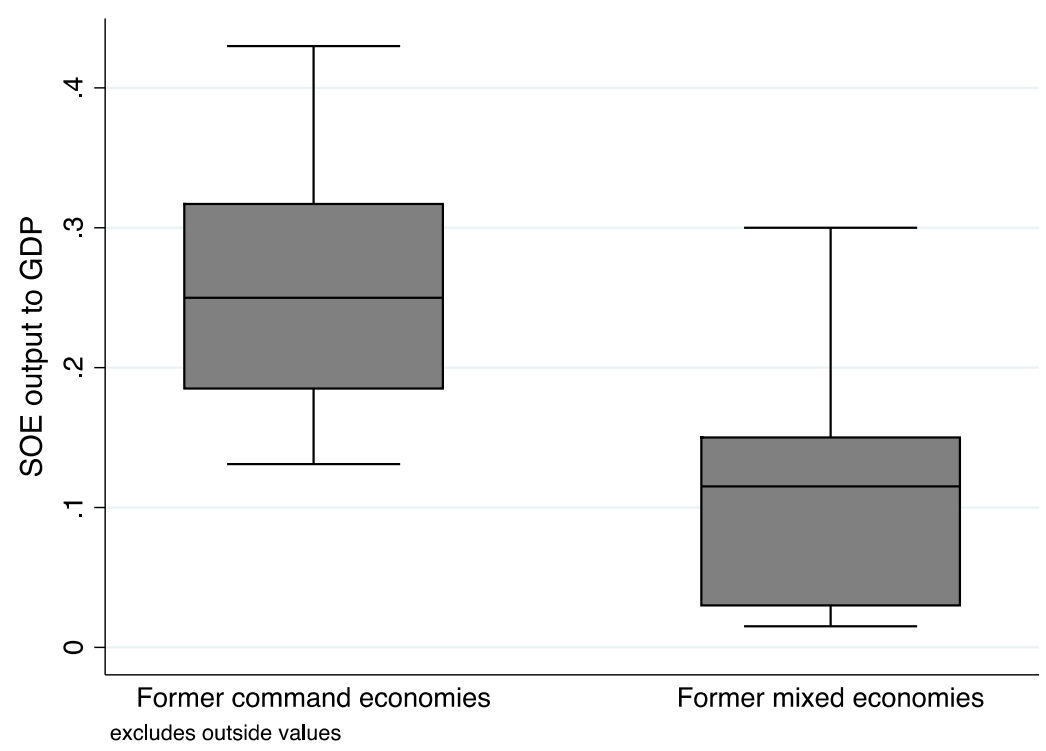

Figure 3. SOE Output to GDP c. 2010 in Former Command and Mixed Economies

Source: Data from Table 1 matched with data from the appendix of World Bank (1995). Former command economies include China, the Czech Republic, Finland, India, Poland, Russia, Slovak Republic, and Vietnam. Former mixed economies include Belgium, Brazil, Denmark, France, Germany, Greece, Indonesia, Italy, Mexico, The Netherlands, New Zealand, Singapore, Sweden, Thailand, and Turkey.

Furthermore, countries in which the state had a larger presence in the economy in 1980 tend to have governments with more SOEs in general and more minority investments in corporations in later years. Figures 4 and 5 depict these relationships in simple scatter plots. Figure 4 shows SOE output to GDP circa 2010 in former mixed economies and former command economies. Former command economies tended to preserve a heavier presence of the state in the ownership of corporations today. We interpret these positive correlations as evidence consistent with the path-dependence view. Consistent with Stark $(1994,1996)$, former socialist countries in Easter Europe 
tend to have the largest presence of Leviathan both as a majority and as a minority shareholder.

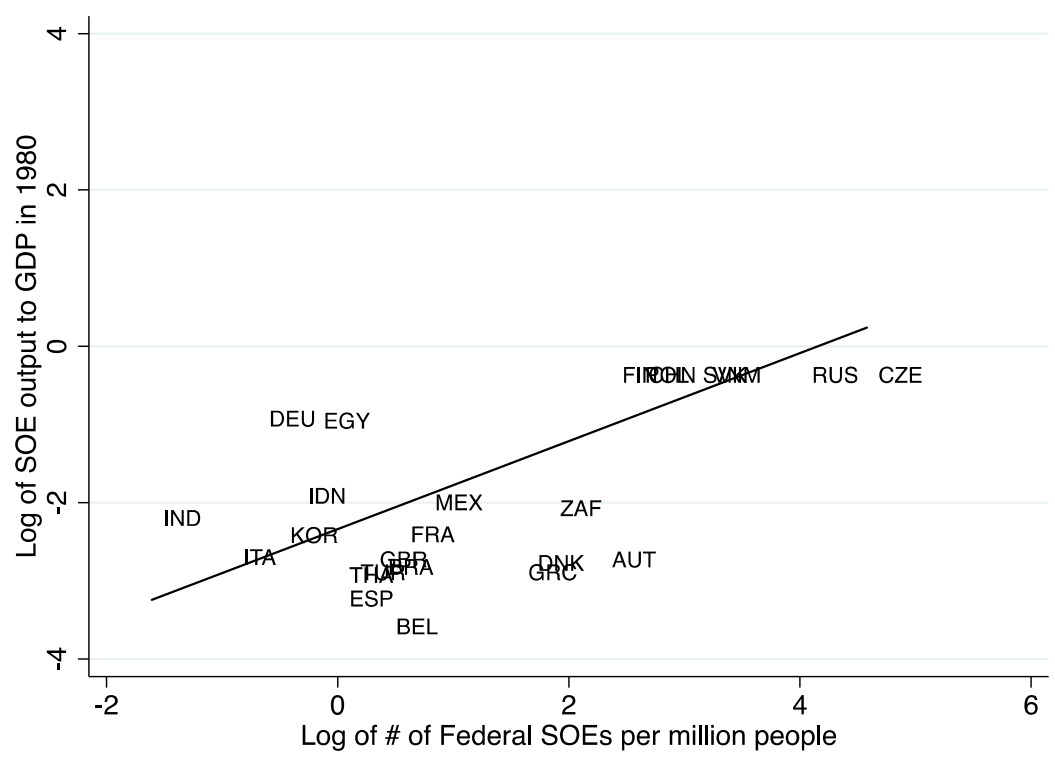

\section{Figure 4. SOE Output to GDP in 1980 vs. the Number of Federal SOEs per Million People (circa 2010)}

Source: See Table 1 and Figure 3.

There is also strong path-dependence when it comes to the number of companies in which the government has minority ownership and the level of SOE output to GDP in 1980. Figure 5 shows that this correlation is high and that the countries in which Leviathan acts more as minority shareholder are also former command economies (e.g., Eastern European countries, Russia, Finland). 


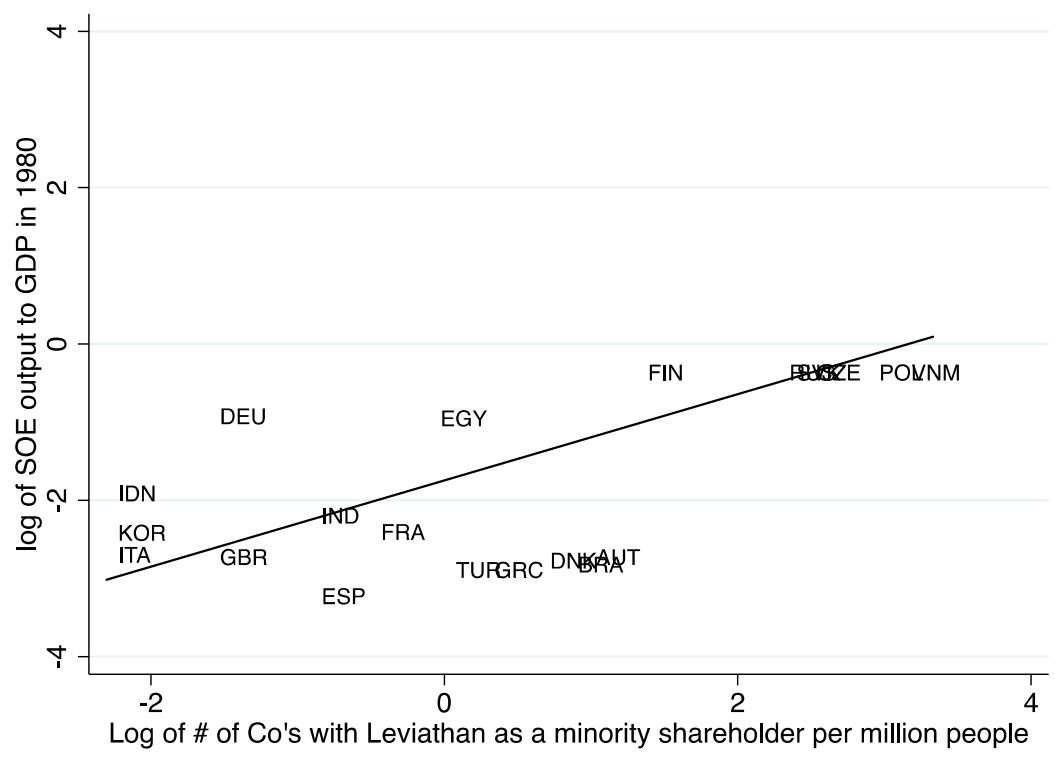

Figure 5. SOE Output to GDP in 1980 vs. the Number of Companies with the Government as a Minority Shareholder per Million People (circa 2010)

Source: See Table 1 and Figure 3.

\section{Varieties of State Capitalism: Features and Performance Implications}

We now consolidate the previous theoretical discussion in a comparative framework describing key attributes of each variety of state capitalism and its implications for the performance of firms and social welfare. For the sake of comparison, we also consider features of private ownership. As indicated in Table 5, we identify four general traits that should greatly differ across modes: the extent to which each mode creates agency problems (i.e. managers whose goals are misaligned with firmlevel objectives); the resulting state capacity to coordinate and enforce societal objectives in the economy; the observed level of cronyism defined by the extent to which political connections yield private companies favors from the government; and the rigidity of 
allocations in the economy, indicated by the degree to which new, entrepreneurial firms enter the system while old, inefficient firms exit. We next describe these traits in more detail.

Table 5. The Modes of State Capitalism in Comparative Perspective

\begin{tabular}{|l|c|c|c|}
\cline { 2 - 4 } \multicolumn{1}{c|}{} & $\begin{array}{c}\text { Leviathan as a } \\
\text { majority investor }\end{array}$ & $\begin{array}{c}\text { Leviathan as a } \\
\text { minority investor }\end{array}$ & $\begin{array}{c}\text { Private } \\
\text { ownership }\end{array}$ \\
\hline $\begin{array}{l}\text { Agency problems within } \\
\text { firms }\end{array}$ & HIGH & MODERATE & LOW \\
\hline $\begin{array}{l}\text { State capacity to } \\
\text { coordinate the economy } \\
\text { and attain social goals }\end{array}$ & HIGH & MODERATE & LOW \\
\hline $\begin{array}{l}\text { Potential for (public- } \\
\text { private) cronyism }\end{array}$ & MODERATE & HIGH & LOW \\
\hline $\begin{array}{l}\text { Flexibility of allocations } \\
\text { (ease of entry and exit) }\end{array}$ & LOW & MODERATE & HIGH \\
\hline
\end{tabular}

Agency problems

The problem of delegating decisions to agents whose objectives may not be aligned with those of principals has been long discussed by agency theorists (Jensen \& Meckling, 1976). The remedies for principal-agent misalignment normally involve performance-contingent incentive contracts for managers, direct monitoring by principals, or a combination of both. Those remedies are far more difficult to implement in SOEs than in privately owned firms. Thus, incentive contracts usually work best when there are objective, readily observable performance metrics such as profits or share prices (Holmstrom \& Milgrom, 1991). However, as suggested by the social view, governments often add social objectives in the management of SOEs, and this may lead 
to confusing goals (Bai \& Xu, 2005). Should managers maximize profits, minimize salaries, or maximize employment? Furthermore, Williamson (1999) submits that lowpowered incentives to managers are a defining feature of state organization, a feature that will guarantee probity (e.g. managers may not be too incentivized to increase profits at the expense of more general social objectives).

Monitoring in public bureaucracies is also challenging (Alchian, 1965; De Alessi, 1980). Many activities in the public sector involve multiple principals dispersed across various domains (Dixit, 2002; Moe, 1984). For instance, if the objective of an SOE is to maximize social welfare, it is not clear who the relevant stakeholder is: Is it society as a whole? Is it the citizens of the city where the company operates? Or, is it the workers of the company themselves? State organizations also lack a well-defined group of monitors, such as shareholders actively participating in corporate boards. In fact, governments may appoint politicians or politically-connected actors to "monitor" SOEs, thereby leading to the fundamental question of "who monitors the monitors" or "who guards the guardians" (Cabral \& Lazzarini, 2010; Hurwicz, 2008). Unlike shareholders of private firms, those appointed board members do not have their wealth at stake when executing their monitoring duties. In addition, managers in SOEs do not have the threat of a hostile takeover when they underperform relative to their peers, and do not face risk of bankruptcy because they know the government will recapitalize or bail out the company if it becomes insolvent (Shleifer, 1998; Vickers \& Yarrow, 1988). 
Agency considerations have been largely employed to explain the empirical finding that SOEs with majority state control usually underperform private companies (e.g. Boardman \& Vining, 1989; Chong \& Lopez-de-Silanes, 2005; Kikeri, Nellis, \& Shirley, 1992; La Porta \& López-de-Silanes, 1999; Yiu, Bruton, \& Lu, 2005); for a review, see Megginson and Netter (2001). What then can be said about the hybrid mode where Leviathan is a minority investor? Because in that hybrid mode the state does not directly control the firms, we should generally expect that the aforementioned agency problems will be less intense in private companies in which the government is only a minority investor, compared to state-controlled SOEs. However, there may be residual interference in PPFs or firms in which the government has minority stakes. Governments may participate in coalitions with other shareholders so as to appoint politically-connected managers and influence decisions based on considerations other than efficiency, potentially attenuating managerial incentives and making it more difficult to attract high-skilled personnel. Thus, agency problems in the hybrid mode should be at intermediate levels between the polar modes of full state control and private ownership. Some studies of privatization and PPFs confirm that in some performance dimensions they fare better than state-owned, but not necessarily better than private companies (Boardman \& Vining, 1989; Majumdar, 1998).

State capacity to coordinate the economy and attain social goals

The industrial policy and social views emphasize that state ownership can help solve market failure and attain social objectives beyond pure profit maximization. 
According to these views, the overall desire to coordinate economic development will therefore mandate some form of "entrepreneurial" governmental action. Arguably, SOEs with full state control can be a vehicle to foster long-term, fixed investments and establish myriad industrial "linkages" by fiat. Indeed, many authors note that the late industrialization of countries in Latin America and South Asia involved some form of direct governmental action through SOEs (Di John 2009; Jones \& Sakong, 1980; Trebat, 1983; Wade, 1990).

As for the hybrid mode of Leviathan as a minority investor, the government's capacity to implement such coordination will depend on the residual interference in firms where the state has minority stakes. When governments invest in or lend to multiple private firms without any concerted action with majority shareholders, their ability to influence decisions will not be much greater than it would be in the context of privately-owned, autonomous firms mostly focused on profit maximization. However, as noted before, governments may form coalitions with other owners and therefore influence decision making more indirectly. Because such coalitions are not always possible, the mode where Leviathan is a minority shareholder should yield moderate ability for governments to intervene, compared to the mode where SOEs are pervasive.

Level of (public-private) cronyism

Recall our previous discussion of cronyism as a mechanism through which politically-connected private actors receive favors from the state. In the stylized mode where Leviathan is a majority investor, the pervasiveness of state-controlled SOEs 
implies that there will be fewer private actors who can directly benefit from state initiatives. Although state bureaucrats and their cronies can establish mutual ties for their own benefit, most allocations will be influenced by and within the state through state bureaus and state-controlled corporations. China is an example, with several stateowned firms whose managers are closely tied to the government and to the Communist Party (Lin \& Milhaupt, 2011).

In contrast, in the Leviathan as a minority investor mode, the presence of several private, controlling owners whose firms largely draw from state capital magnifies the opportunities for cronyism. Consider, for instance, the case of subsidized loans by development banks. In cases where banks provide massive amounts of capital to industry and where subsidized interest rates are much lower than market rates, the benefit to invest in connections to attract cheap capital increases substantially. For instance, Lazzarini, Musacchio, Bandeira-de-Mello and Marcon (2012) find that allocations by Brazil's BNDES depend on whether firms donated to elected political candidates, and that those allocations do not have a consistent effect on observed firmlevel investment decisions. In other words, subsidized state capital may be channeled to politically-connected capitalists who could probably attract capital elsewhere.

Therefore, the more extensive and permeable public-private interface that prevails when Leviathan is a minority investor suggests that the level of cronyism will tend to be more prevalent in this hybrid mode. In the polar mode where the state is a majority investor, most allocations actually flow within the state apparatus. The latter, 
in turn, should be more prone to crony ties than the stylized mode of private ownership with minimal state interference.

Flexibility of allocations (ease of entry and exit)

Private ownership with minimal state interference is often associated with an inherent ability to churn out new entrepreneurial firms while at the same time avoiding the persistence of unproductive incumbents (Ahroni, 1986; Baumol, Litan, \& Schramm, 2007; Bremmer, 2010). A key aspect of this mode, in its stylized form, is a low level of entry and exit barriers, thereby facilitating flexible adjustments to changing conditions (e.g. technological disruptions or the emergence of more competitive foreign players). Such flexible adjustments are more difficult under state capitalism. Governments may want to shield domestic firms and SOEs against foreign competition, or build national champions with the use of subsidized credit and import tariffs. As suggested by the path dependence view, such interventions likely have persistent effects. Furthermore, given that direct state involvement is more pervasive in the majority Leviathan mode, flexible adjustments will be easier when Leviathan is a minority investor-even though the existence of political connections will create entry and exit barriers superior to the pure private ownership mode. For instance, cronyism has been used as one of the explanations for the bail out of large private groups in East Asia after the crisis of 1997 (Kang, 2002). 


\section{Which factors influence the emergence of each mode of state capitalism?}

Given the previous discussion on the advantages and drawbacks of the various forms of state capitalism, a natural question is: which conditions will make a given mode more suitable? By "suitable," we mean the degree to which each mode will allow for long-term economic development and firm-level performance, after taking into account existing constraints posed by country-level institutions and historical conditions. Figure 6 summarizes our main arguments, which are expanded below.

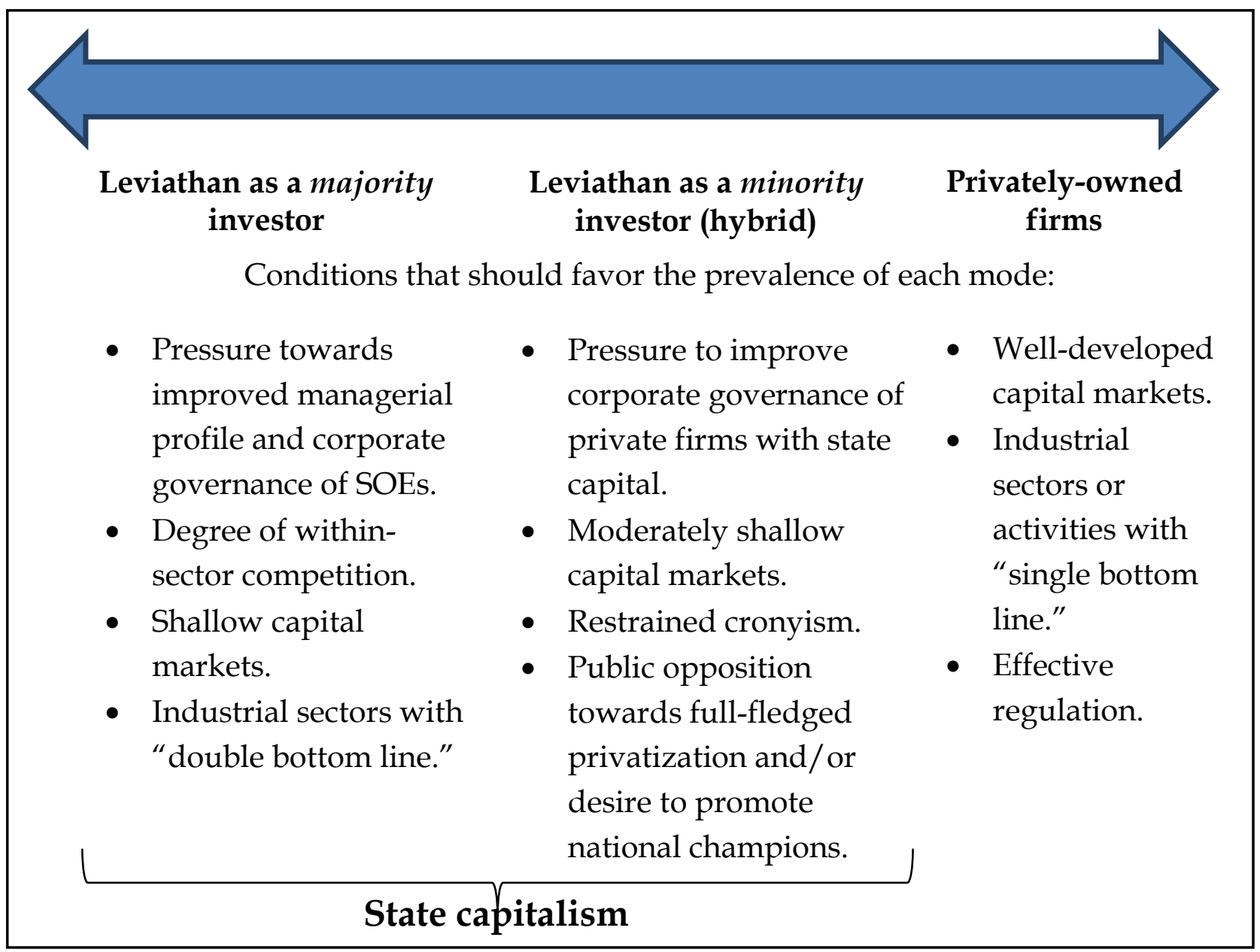

Figure 6. Varieties of State Capitalism: Conditions Affecting the Prevalence of Each Mode. 
Conditions which favor the mode of Leviathan as a majority investor

Pressure towards improved managerial profile of SOEs. The performance of the majority Leviathan mode should largely increase when governments prioritize the selection of professional, competent, and public-minded managers. A clear hypothesis coming from studies of public organizations follows the Weberian idea that bureaucracies perform best when public managers are skilled, technical professionals free of political interference (Ahroni, 1986; Amsden, 1989; Lioukas, Bourantas, \& Papadakis, 1993; Miller, 2000; Schneider, 1991). Management of SOEs, in this view, will be delegated to public servants with a sense of duty and with preferences towards rectitude and professionalism (Wilson, 1989). Although such delegation may at first glance exacerbate the agency problem -i.e. professional managers will be less accountable to their governments - managerial autonomy may create incentives for the development of a competent, skilled bureaucratic class with long careers in their own industry. Trebat (1983, p. 79) claims that "a competent staff can develop, over time, a reputation for professionalism that discourages interference by less-well-trained civil servants in the ministry." Furthermore, skilled technical professionals may over time develop distinctive competencies in their industry or activity (Klein, Mahoney, McGahan, \& Pitelis, 2011); autonomy will thus beget further learning and specialization. 
Pressure toward improved governance of SOEs. The Leviathan as a majority investor mode can also be improved with programs to reform corporate governance of SOEs. These firms may more generally mimic the governance practices of privately owned firms - as proclaimed by the so-called New Public Management view of state organizations (Barberis, 1998; Flores-Macias \& Musacchio, 2009; Lane, 2000). Thus, managerial delegation to technical professionals may be accompanied by either the introduction of salaries with bonuses or prizes based on meeting specific goals, or promotions within the government based on merit. In China, for instance, performance-contingent contracts for SOE managers are common (Bai \& Xu, 2005; Mengistae \& $\mathrm{Xu}, 2004)$. Public listing of SOEs through the sale of minority state shareholdings may additionally improve the governance of SOEs because it should reveal company-level information and allow external investors to more effectively monitor SOEs. Thus, analyzing data from Indian SOEs, Gupta (2005) finds that (minority) public listing improves sales, profits, and productivity. ${ }^{13}$

Likewise, states can reform the corporate governance of SOEs by creating boards with skilled, independent external members who improve monitoring of management performance. Kole and Mulherin (1997), for instance, analyze an interesting event in the United States when the government took over subsidiaries of enemy countries during and after World War II. They find no significant differences between those government-

${ }^{13}$ Gupta (2005) refers to the sale of minority stakes by the government as "partial privatization." In our usage of the term, however, partially privatized firms are those in which majority control is sold to private owners. 
owned firms and private counterparts in similar sectors. To explain this result, they note that the government crafted new boards with a more "hands-off, supervisory role" (p. 8), while at the same time retaining technical managers to assure that each business will be subject to "the supervision of men familiar with its operations" (p. 9).

Reforms to improve governance of SOEs also mandate changes in laws that effectively protect minority shareholders. Thus, if governments pursue a double bottom line, then their influence on SOEs may harm those shareholders (e.g. keeping prices low to curb inflation, at the expense of reduced firm-level profitability). Pargendler (2012) discusses these risks in detail and offers some policy recommendations.

Degree of within-sector competition. Majority state control may be better suited to firms in sectors characterized by a high degree of competition. Several authors have stressed that the efficiency of SOEs may be affected by their competitive environment (Bartel \& Harrison, 2005; Boardman \& Vining, 1989; Caves \& Christensen, 1980; Lioukas et al., 1993; Vickers \& Yarrow, 1988). When SOEs have to compete for contracts or clients, there is less room for excessive governmental interference because otherwise they will have less resources and leeway to invest and respond to market pressure. Consistent with this hypothesis, Bartel and Harrison's (2005) empirical analysis of private and public firms in Indonesia reveals that "there may be an agency problem associated with public-sector ownership, but only when firms are given access to government financing or protected from import competition or foreign ownership" ( $\mathrm{p}$. 
142). They point out that reforms along the lines of enhancing competitive pressure for SOEs can be a useful and perhaps easier to implement in countries with strong objections against privatization.

Shallow capital markets. The industrial policy view submits that governmental action at the industrial level will be particularly useful when shallow, underdeveloped capital markets preclude private entrepreneurial action. In our view, shallow capital markets not only make it difficult for firms to access capital, but they also make it harder for investors to obtain company-level information to help them monitor and discipline managers. For instance, in countries with developed stock markets, investors have access to company information regularly. Moreover, stock markets with active investors and high liquidity reduce agency problems by making managers worried about possible takeover threats. For this reason, less developed capital markets make takeovers less likely and magnify governance conflicts (Dyck \& Zingales, 2004; Nenova, 2005). Thus, the benefits of the majority Leviathan mode will tend to increase in countries at very early stages of capital market development. Lending some support for this claim, Sarkar, Sarkar and Bhaumik's (1998) comparison of state-owned and private banks in India conclude that, in the absence of well-functioning capital markets, private companies are not unambiguously superior to SOEs. As noted before, Bortolotti, Fantini and Siniscalco (2004) also find that privatization tends to be positively associated with developed financial markets. 
Pressures or desires to create industrial sectors that pursue a "double bottom line."

SOEs will also allow governments to pursue policies that create "double bottom line" to managers. As implied by the agency perspective, private companies will have a hard time attracting and incentivizing skilled managers when objectives are multiple and diffuse. For instance, state-owned banks may be created to support governmental policies promoting cheap credit or targeted capital to certain sectors (Yeyati et al., 2004). "Resource" sectors such as mining or oil extraction also tend to exhibit double-bottom line behavior because governments often treat these sectors as "strategic": managers of those firms are supposed not only to pursue profitability, but also use the proceeds from mineral extraction to develop vertically-linked industries (e.g. equipment, shipping, etc.) or to support social redistribution programs..$^{14}$

Conditions that favor the mode of Leviathan as a minority investor

Moderately shallow capital markets. We use the qualifier "moderately" because, without some degree of capital market development, governments may not have at their disposal an emerging private sector with established mechanisms to channel resources and monitor their investments - as is the case, for instance, when state-owned funds invest in publicly listed shares. However, as capital markets become more developed, the benefits of government investments in minority positions in private firms will likely diminish. Firms will more and more have access to external financing and alternative

${ }^{14}$ Sometimes, however, the double-bottom argument is inefficiently used by governments for political gain. The so-called resource curse literature, for instance, argues that governments may control country-specific natural resources to implement populist initiatives and support corrupt deals (for a review, see Di John 2009; Frankel, 2010). 
forms of capitalization (e.g. IPOs, publicly traded debentures, depository receipts, among others). We thus submit that the Leviathan as a minority investor mode will be more appropriate in intermediate stages of capital market development. For instance, Inoue, Lazzarini and Musacchio (2012) find that the positive effect of minority equity allocations by the Brazilian Development Bank, BNDES, on firm performance and investment was significant in the 1990s, but diminished thereafter. They argue that one of the likely explanations is that capital markets in Brazil grew more rapidly after 2003 and their regulation improved since 2001 (e.g., the ratio of stock market capitalization to GDP in Brazil jumped from 19 percent in 1995 to 73 percent in 2009).

Restrained cronyism. Minority state ownership of firms will likely work best in countries with a well-established bureaucratic ethos of professionalism and publicmindedness. This is because, as Ades and DiTella (1999) show in their theoretical model, there is risk of having corruption when bureaucrats are in charge of selecting national champions that receive government favors (e.g., subsidized credit). That is why the literature on bureaucrats and industrial policy emphasizes that importance of having a skilled technical staff with superior analytical capabilities and a sense of professionalism in their policy-making duties behind the decision of where to invest government money (Evans, 1995; Schneider, 1991). Wade (1990, p. 225) posits that, in Taiwan, "industrial policy-making and implementation have been done largely by people trained in engineering and, at senior levels, with close knowledge of Japan's industrial policies." Authors such as Amsden (1989) and Rodrik (2004) also stress the 
importance of planning and clear indicators (e.g. firm-level export performance) to decide whether private targets deserve or not extended support. With transparent criteria to define targets and disciplining mechanisms to halt capital injections in case of poor performance, the negative effect of cronyism in the minority Leviathan mode should be greatly reduced.

Public opposition towards full-fledged privatization and/or desire to promote national champions. The path dependence view discussed earlier suggests that large-scale, outright privatization may not be palatable to the public opinion. Thus, the mode where Leviathan is a minority investor will likely occur in settings where governments are pressured to increase the efficiency of public enterprises through private management but when, at the same time, governments want to signal to the public that they are not completely neglecting their role as providers of capital and agents of economic development. State investments in minority equity positions, therefore, should be common in countries with preferences towards building national champions with some degree of governmental support (see e.g. Bremmer, 2010, p. 67).

Pressure to improve corporate governance of private firms with minority state capital. Minority state ownership of firms can be suitable in situations where certain corporate structures, particularly pyramidal business groups, are avoided. Since Leff's (1978) original contribution, scholars have proposed that business groups -i.e., collections of firms under the same controlling entity - provide credit-constrained firms with financing opportunities that flow through internal capital markets (Khanna \& Palepu, 
1997, 2000; Khanna \& Yafeh, 2007; Wan \& Hoskisson, 2003). But if capital markets internal to groups substitute for the need for external financing, we should expect governmental capital to be more effective when target firms are not affiliated to groups. The latter should be relatively more constrained in their investment opportunities than firms that have access to internal, group-level capital.

Moreover, groups tend to magnify the risk of minority shareholder expropriation. Here the agency problem occurs the other way around: instead of a majority Leviathan creating management conflicts, the state will be a minority investor who can be expropriated by majority private owners. This will likely occur when private groups are organized as complex pyramids involving firms that have stakes in other firms and so successively (Morck, Wolfenzon, \& Yeung, 2005). Thus, state capital may be "tunneled" through complex pyramids to support controlling owners' private projects or rescue struggling internal units (Bae, Kang, \& Kim, 2002; Bertrand, Mehta, \& Mullainathan, 2002). The government may thus benefit a group's majority owners without necessarily improving the performance of the companies in which it invests. Furthermore, while credit-constrained firms may be able bolster fixed investments with the help of governmental capital allocations, tunneling within business groups implies that new allocations may be redirected for reasons other than to support those fixed investments. Consistent with this hypothesis, Giannetti and Laeven (2009) and Inoue, Lazzarini and Musacchio (2012) find that the positive performance effect of minority 
state equity - via pension funds and development banks respectively -is reduced when target firms belong to business groups.

\section{Conditions that favor privately-owned firms}

It is also useful to close our argument by discussing how those identified conditions would affect the choice of a more market-oriented, privately-owned mode of economic organization. We already discussed that well-developed capital markets diminish the benefits of state interventions to infuse capital in the economy; thus, the mode of pure private ownership works best when capital markets are widely developed. Furthermore, this mode is appropriate for industrial sectors and activities with "single bottom line;" think, for instance, of consumer goods or retail companies where objective indicators such as profitability and sales are straightforward performance dimensions. Finally, governments that are able to craft effective regulatory systems should be less dependent on direct or indirect state investments to improve infrastructure or promote certain sectors, while at the same time avoiding distortions that might occur when firms neglect performance dimensions valued by the population (Bortolotti \& Perotti, 2007). For instance, examining events of telecom privatization in Africa and Latin America, Wallsten (2001) observes that while privatization in tandem with effective regulatory systems appear to improve a host of service performance dimensions, privatization alone results in lower service penetration to the population (i.e. the capacity of the network to connect several lines). 


\section{Concluding remarks}

This paper makes three general arguments. First, state capitalism in the twentyfirst century combines majority ownership of SOEs with a hybrid form that includes minority equity investments as well as other forms of support for private firms (e.g., subsidized loans). Second, all of those forms are present around the world, both in rich and poor countries, and in most cases they co-exist. Although some countries appear to have a prevalence of the minority investor mode (e.g. Brazil, India) while other countries emphasize the majority mode (e.g. Russia, China), in most cases the two modes jointly occur. Three, the emergence of those modes is explained by a host of environmental, political and historical factors; and the economic performance of each mode will depend on certain contingencies that should affect their benefits and costs (e.g. the economic distortions that they may generate). We carefully identify those contingencies, in light of recent theoretical and empirical developments in the field.

Our discussion opens several avenues for further research. For instance, for the Leviathan as a majority investor mode, most of the literature on SOEs focused on showing how those firms underperformed private companies. Yet there is significant variation in the performance of SOEs even within the same industry; and research explaining that variation is surprisingly scant. Our previous discussion suggests some factors that can help explain such performance heterogeneity (e.g. managerial and governance features of SOEs), but much more work is need to improve our understanding of when and in which conditions some SOEs will outperform other 
SOEs and even private firms. This point is important because some countries are reluctant to privatize certain SOEs in certain "strategic" sectors. In those conditions, the Leviathan as a majority investor mode is a given, and hence the exercise is to find ways to make it work.

When it comes to Leviathan as a minority investor mode, there is also a long list of unanswered questions. For instance, when do government investments in minority equity positions improve firm performance or allow firms to invest in projects they would not otherwise pursue? Are these minority equity investments more effective when financial markets are more developed or when corporate governance regulation is stricter? Which particular conduit of minority investment is more appropriate, given that myriad channels are available for governments (e.g. development banks, pension funds, sovereign wealth funds, and so on)? How to reduce the potential for cronyism that can accompany such minority allocations? How to manage partially privatized firms? We hope that the discussion present here will stimulate novel research to advance our understanding by answering these and other questions raised by the recent dissemination of varied forms of state capitalism.

\section{References}

Ades, A., \& Di Tella, R. 1997. National champions and corruption: some unpleasant interventionist arithmetic. The Economic Journal, 107(443): 1023-1042.

Ahroni, Y. 1986. The evolution and management of state owned enterprises. Cambridge: Ballinger Publishing.

Alchian, A. A. 1965. Some economics of property rights. Il Politico, 30: 816-829.

Amsden, A. H. 1989. Asia's next giant: South Korea and late industrialization. New York: Oxford University Press. 
Armendáriz de Aghion, B. 1999. Development banking. Journal of Development Economics, 58: 83-100.

Bae, K.-H., Kang, J.-K., \& Kim, J.-M. 2002. Tunneling or value added? Evidence from mergers by Korean business groups. The Journal of Finance, 57(6): 2695-2740.

Bai, C.-E., \& Xu, L. C. 2005. Incentives for CEOs with multitasks: evidence from Chinese state-owned enterprises. Journal of Comparative Economics, 33: 517-539.

Barberis, P. 1998. The New Public Management and a new accountability. Public Administration Review, 76(3): 451-470.

Bartel, A. P., \& Harrison, A. E. 2005. Ownership versus environment: disentangling the sources of public-sector inefficiency. The Review of Economics and Statistics, 87(1): 135-147.

Baumol, W. J., Litan, R. E., \& Schramm, C. J. 2007. Good capitalism, bad capitalism, and the economics of growth and prosperity. New Haven \& London: Yale University Press.

Bebchuk, L. A., \& Roe, M. J. 1999. A theory of path dependence in corporate ownership and governance. Stanford Law Review, 52(1): 127-170.

Bennedsen, M. 2000. Political ownership. Journal of Public Economics, 76: 559-581.

Bennett, J., \& Iossa, E. 2006. Building and managing facilities for public services. Journal of Public Economics, 90: 2143-2160.

Bertrand, M., Mehta, P., \& Mullainathan, S. 2002. Ferreting out tunneling: an application to Indian business groups. Quarterly Journal of Economics, 117(1): 121-148.

Boardman, A. E., \& Vining, A. R. 1989. Ownership and performance in competitive environments: a comparison of the performance of private, mixed, and stateowned enterprise. Journal of Law and Economics, 32: 1-33.

Bortolotti, B., \& Faccio, M. 2009. Government control of privatized firms. The Review of Financial Studies, 22(8): 2907-2939.

Bortolotti, B., Fantini, M., \& Siniscalco, D. 2004. Privatisation around the world: evidence from panel data. Journal of Public Economics, 88(1-2): 305-332.

Bortolotti, B., \& Perotti, E. 2007. From government to regulatory governance: privatization and the residual role of the state. World Bank Research Observer, 22(1): 53-66.

Bower, J. L., Leonard, H. B., \& Paine, L. S. 2011. Capitalism at risk: rethinking the role of business. Boston: Harvard Business Review Press.

Boyko, M., Shleifer, A., \& Vishny, R. W. 1996. A theory of privatization. Economic Journal, 106: 309-319.

Bremmer, I. 2010. The end of the free market: who wins the war between states and corporations? New York: Portfolio/Penguin.

Bruck, N. 1998. The role of development banks in the Twenty-First Century. Journal of Emerging Markets, 3: 39-67.

Cabral, S., \& Lazzarini, S. G. 2010. The 'guarding the guardians' problem: an empirical analysis of investigations in the internal affairs division of a police organization, Working paper. 
Cabral, S., Lazzarini, S. G., \& Azevedo, P. F. 2010. Private operation with public supervision: evidence of hybrid modes of governance in prisons. Public Choice, 145(1-2): 281-293.

Cameron, R. 1961. France and the economic development of Europe, 1800-1914. Princeton: Princeton University Press.

Caves, D. W., \& Christensen, L. R. 1980. The relative efficiency of public and private firms in a competitive environment: the case of Canadian railroads. Journal of Politica Economy, 88(5): 958-976.

Chong, A., \& Lopez-de-Silanes, F. (Eds.). 2005. Privatization in Latin America: myths and reality. Washington DC: World Bank and Stanford University Press.

Claessens, S., Feijen, E., \& Laeven, L. 2008. Political connections and preferential access to finance: the role of campaign contributions. Journal of Financial Economics, 88: 554-580.

Coe, N. M., Dicken, P., \& Hess, M. 2008. Global production networks: realizing the potential. Journal of Economic Geography, 8(3): 271-295.

De Alessi, L. 1980. The economics of property rights: a review of the evidence. Research in Law and Economics, 2: 1-47.

De Paula, G. M., Ferraz, J. C., \& Iootty, M. 2002. Economic liberalization and changes in corporate control in Latin America. The Developing Economies, 40(4): 467-496.

Di John , J. 2009. From windfall to curse? Oil and industrialization in Venezuela, 1920 to the present. University Park: Penn State University Press.

Dinç, I. S. 2005. Politicians and banks: Political influences on government-owned banks in emerging markets. Journal of Financial Economics, 77: 453-479.

Dinç, I. S., \& Gupta, N. 2011. The decision to privatize: finance and politics. Journal of Finance, 66(1): 241-269.

Dixit, A. 2002. Incentives and organizations in the public sector: an interpretative review. The Journal of Human Resources, 37(4): 696-727.

Duncan, J. S. 1932. Public and private operation of railways in Brazil. New York: Columbia University Press.

Durant, R. F., \& Legge Jr., J. S. 2002. Politics, public opinion, and privatization in France: assessing the calculus of consent for market reforms. Public Administration Review, 62(3): 307-323.

Dyck, A., \& Zingales, L. 2004. Private benefits of control: an international comparison. Journal of Finance, 59(2): 537-600.

Evans, P. 1995. Embedded autonomy: states and industrial transformation. Princeton: Princeton University Press.

Faccio, M. 2006. Politically connected firms. American Economic Review, 96(1): 369-386.

Falck, O., Gollier, C., \& Woessmann, L. 2011. Arguments for and against policies to promote national champions. In O. Falck, C. Gollier, \& L. Woessmann (Eds.), Industrial policy for national champions: 3-9. Cambridge: MIT Press.

Flores-Macias, F., \& Musacchio, A. 2009. The return of state-owned enterprises: should we be affraid?, Harvard International Review. April 4 
Frankel, J. 2010. The natural resource curse: a survey, Harvard Kennedy School Research Working Paper Series 10-005.

Gerschenkron, A. 1962. Economic backwardness in historical perspective. Cambridge: Harvard University Press.

Giannetti, M., \& Laeven, L. 2009. Pension reform, ownership structure, and corporate governance: evidence from a natural experiment. The Review of Financial Studies, 22(10): 4091-4127.

Gupta, N. 2005. Partial privatization and firm performance. Journal of Finance, 60: 9871015.

Haber, S. 2002. Introduction: the political economy of crony capitalism. In S. Haber (Ed.), Crony capitalism and economic growth in Latin America: theory and evidence: xi-xxi. Stanford: Hoover Institution Press.

Hall, P. A., \& Soskice, D. 2001. An introduction to varieties of capitalism. In P. A. Hall, \& D. Soskice (Eds.), Varieties of capitalism: the institutional foundations of comparative advantage: 1-70. Oxford: Oxford University Press.

Hart, O. D., Shleifer, A., \& Vishny, R. W. 1997. The proper scope of government: theory and an application to prisons. Quarterly Journal of Economics, 112(4): 1127-1161.

Hirschman, A. O. 1982. Shifting involvements: private interest and public action. Princeton: Princeton University Press.

Holmstrom, B., \& Milgrom, P. 1991. Multitask principal-agent analyses: incentive contracts, asset ownership, and job design. Journal of Law, Economics and Organization, 7: 24-52.

Hurwicz, L. 2008. But who will guard the guardians? American Economic Review, 98(3): 577-585.

Inoue, C. F. K. V., Lazzarini, S. G., \& Musacchio, A. 2012. Leviathan as a minority shareholder: firm-level performance implications of equity purchases by the government Working Paper, Insper Institute of Education and Research.

Jensen, M. C., \& Meckling, W. H. 1976. Theory of the firm: managerial behavior, agency costs and ownership structure. Journal of Financial Economics, 3: 305-360.

Jones, L., \& Sakong, I. 1980. Government, business, and entrepreneurship in economic development: The Korean case. Cambridge: Harvard University Press.

Kaldor, N. 1980. Public or private enterprise - the Issue to be considered. In W. J. Baumol (Ed.), Public and private enterprises in a mixed economy: 1-12. New York: St. Martin's.

Kang, D. 2002. Crony capitalism: corruption and development in South Korea and the Philippines. Cambridge: Cambridge University Press.

Kaufmann, D., \& Siegelbaum, P. 1996. Privatization and corruption in transition economies. Journal of International Affairs, 50(2): 419-458.

Khanna, T., \& Palepu, K. 1997. Why focused strategies may be wrong in emerging markets. Harvard Business Review(July-August): 3-10.

Khanna, T., \& Palepu, K. 2000. The future of business groups in emerging markets: long-run evidence from Chile. Academy of Management Journal, 43(3): 268-285. 
Khanna, T., \& Yafeh, Y. 2007. Business groups in emerging markets: paragons or parasites? Journal of Economic Literature, 45: 331-372.

Kikeri, S., Nellis, J. N., \& Shirley, M. M. 1992. Privatization: the lessons of experience. Washington, D.C.: World Bank.

Klein, P. G., Mahoney, J. T., McGahan, A. M., \& Pitelis, C. N. 2011. Resources, capabilities and routines in public organization, Working paper, University of Missouri, Columbia.

Kole, S. R., \& Mulherin, J. H. 1997. The government as a shareholder: a case from the United States. Journal of Law and Economics, 40(1): 1-22.

Kornai, J. 1979. Resource-constrained versus demand-constrained systems. Econometrica, 47(4): 801-819.

Krueger, A. O. 1990. Government failures in development. Journal of Economic Perspectives, 4(3): 9-23.

Krugman, P. 1993. The current case for industrial policy. In D. Salvatores (Ed.), Protectionism and world welfare: 160-179. Cambridge: Cambridge University Press.

Kuczynski, P.-P. 1999. Privatization and the private sector. World Development, 27(1): 215-224.

La Porta, R., \& López-de-Silanes, F. 1999. The benefits of privatization: evidence from Mexico. Quarterly Journal of Economics, 114: 1193-1242.

La Porta, R., Lopez-de-Silanes, F., Shleifer, A., \& Vishny, R. W. 1998. Law and finance. Journal of Political Economy, 106(6): 1113-1155.

Lane, J.-E. 2000. New public management. New Fetter Lane: Routledge.

Lazzarini, S. G. 2011. Capitalismo de laços: os donos do Brasil e suas conexões. Rio de Janeiro: Campus/Elsevier.

Lazzarini, S. G., Musacchio, A., Bandeira-de-Mello, R., \& Marcon, R. 2012. What do development banks do? Evidence from Brazil, 2002-2009, Insper Working paper, Available at SSRN: http://ssrn.com/abstract $=1969843$.

Leff, N. H. 1978. Industrial organization and entrepreneurship in the developing countries: the economic groups. Economic Development and Cultural Change, 26(4): 661-675.

Levine, R. 2005. Finance and growth: theory and evidence. In P. Aghion, \& S. Durlauf (Eds.), Handbook of economic growth, Vol. 1: 865-934. Amsterdam: Elsevier.

Lin, J. Y., \& Tan, G. 1999. Policy burdens, accountability, and the soft budget constraint. The American Economic Review, 89(2): 426-431.

Lin, L.-W., \& Milhaupt, C. J. 2011. We are the (national) champions: understanding the mechanisms of state capitalism in China, Working paper, Columbia University. Available at SSRN: http://ssrn.com/abstract $=1952623$.

Lioukas, S., Bourantas, D., \& Papadakis, V. 1993. Managerial autonomy of state-owned enterprises: determining factors. Organization Science, 4(4): 645-666.

Majumdar, S. K. 1998. Assessing comparative efficiency of the state-owned mixed and private sectors in Indian industry. Public Choice, 96(1/2): 1-24.

Marshall. 1920. Principles of economics. London: Mcmillan. 
McDermott, G. A. 2003. Embedded politics: industrial networks \& institutional change in postcommunism. Ann Arbor: University of Michigan Press.

Megginson, W. L., \& Netter, J. M. 2001. From state to market: a survey of empircal studies of privatization. Journal of Economic Literature, 39: 321-389.

Mengistae, T., \& Xu, L. C. 2004. Agency theory and compensation of CEOs of Chinese state enterprises. Journal of Labor Economics, 22: 615-637.

Miller, G. J. 2000. Above politics: credible commitment and efficiency in the design of public agencies. International Journal of Public Administration Research and Theory, 10(2): 289-328.

Millward, R. 2005. Private and public enterprise in Europe: energy telecommunications and transport, 1830-1990. Cambridge: Cambridge University Press.

Moe, T. M. 1984. The New Economics of Organization. American Journal of Political Science, 28(4): 739-777.

Morck, R., Wolfenzon, D., \& Yeung, B. 2005. Corporate governance, economic entrenchment, and growth. Journal of Economic Literature, 43(3): 655-720.

Musacchio, A. 2009. Experiments in financial democracy: corporate governance and financial development in Brazil, 1882-1950. Cambridge: Cambridge University Press.

Musacchio, A., \& Staykov, E. 2011. Sovereign wealth funds: barbarians at the gat or white knights of globalization?, Harvard Business School note N9-712-022.

Nee, V., \& Opper, S. 2007. On policized capitalism. In V. Nee, \& R. Swedberg (Eds.), On capitalism: 93-127. Stanford: Stanford University Press.

Nenova, T. 2005. Control values and changes in corporate law in Brazil. Latin American Business Review, 6(3): 1-37.

North, D. C. 1990. Institutions, institutional change and economic performance. Cambridge: Cambridge University Press.

OECD. 2005. OECD, Corporate Governance of State-Owned Enterprises: A Survey of OECD Countries Organisation for Economic Co-operation and Development. Paris.

Pack, H., \& Saggi, K. 2006. Is there a case for industrial policy? A critical survey. The World Bank Research Observer, 21(2): 267-297.

Pargendler, M. 2012. State ownership and corporate governance. Fordham Law Review, 80(6): 2917-2973.

Pistor, K., \& Turkewitz, J. 1996. Coping with hydra - state ownership after privatization. In R. Frydman, C. W. Gray, \& A. Rapaczynski (Eds.), Corporate governance in Central Europe and Russia, Vol. 2. Budapest: Central European University Press.

Rodrik, D. 2004. Industrial policy for the twenty-first century. CEPR Discussion Paper.

Rothbard, M. N. 1973. A future of peace and capitalism. Boston: Allyn and Bacon.

Sapienza, P. 2004. The effects of government ownership on bank lending. Journal of Financial Economics, 72(2): 357-384.

Sarkar, J., Sarkar, S., \& Bhaumik, S. K. 1998. Does ownership always matter? Evidence from the Indian bank industry. Journal of Comparative Economics, 26: 262-281. 
Schneider, B. R. 1991. Politics within the state: elite bureaucrats and industrial policy in authoritarian Brazil. Pittsburgh: University of Pittsburgh Press.

Schneider, B. R., \& Soskice, D. 2009. Inequality in developed countries and Latin America: coordinated, liberal and hierarchical systems. Economy and Society, 38(1): 17-52.

Shapiro, C., \& Willig, R. D. 1990. Economic rationales for the scope of privatization. In E. N. Suleiman, \& J. Waterbury (Eds.), The political economy of public sector reform and privatization: 55-87. London: Westview Press.

Shirley, M., \& Nellis, J. 1991. Public enterprise reform: the lessons of experience. Washington, DC: Economic Development Institute of the World Bank.

Shleifer, A. 1998. State versus private ownership. Journal of Economic Perspectives, 12(4): 133-150.

Shleifer, A., \& Vishny, R. W. 1994. Politicians and firms. The Quarterly Journal of Economics, 109: 995-1025.

Shleifer, A., \& Vishny, R. W. 1998. The grabbing hand: government pathologies and their cures. Cambridge: Harvard University Press.

Stark, D. 1994. Path dependence and privatization strategies in East-Central Europe, Transition to capitalism? The communist legacy in Eastern Europe: 63-99. New Brusnwick: Transaction Publishers.

Stark, D. 1996. Recombinant property in East European capitalism American Journal of Sociology, 101(4): 993-1027.

Toninelli, P. A. 2000. The rise and fall of public enterprise: the framework. In P. A. Toninelli (Ed.), The rise and fall of public enterprise in the Western World: 3-24. Cambridge: Cambridge University Press.

Trebat, T. J. 1983. Brazil's state-owned enterprises: a case study of the state as entrepreneur. Cambridge: Cambridge University Press.

Vaidyanathan, S., \& Musacchio, A. 2012. State Capitalism in India and its implications for investors Harvard Business School, mimeo.

Vickers, J., \& Yarrow, G. 1988. Privatization: an economic analysis. Cambridge: MIT Press.

von Mises, L. 2009. Socialism: an economic and sociological analysis. Auburn: The Ludwig von Mises Institute.

Waclawik-Wejman, A. 2005. Corporate governance of State-Owned Enterprises in Poland, World Bank.

Wade, R. 1990. Governing the market: economic theory and the role of government in East Asian capitalism. Princeton: Princeton University Press.

Wallsten, S. J. 2001. An econometric analysis of telecom competition, privatization, and regulation in Africa and Latin America. The Journal of Industrial Economics, 49(1): 1-19.

Wan, W. P., \& Hoskisson, R. E. 2003. Home country environments, corporate diversification strategies, and firm performance. Academy of Management Journal, 46(1): 27-45. 
Williamson, O. E. 1985. The economic institutions of capitalism. New York: The Free Press.

Williamson, O. E. 1999. Public and private bureaucracies: a transaction cost economics perspective. Journal of Law, Economics and Organization, 15(1): 306-342.

Wilson, J. O. 1989. Bureaucracy: what government agencies do and why they do it. New York: Basic Books.

Wooldridge, A. 2012. The visible hand, The Economist. 01/21/2012

World Bank. 1995. Bureaucrats in business: The economics and politics of government ownership. Oxford: Oxford University Press.

Yeyati, E. L., Micco, A., \& Panizza, U. 2004. Should the government be in the banking business? The role of state-owned and development banks, RES Working Papers 4379, Inter-American Development Bank, Research Department.

Yiu, D., Bruton, G. D., \& Lu, Y. 2005. Understanding business group performance in an emerging economy: acquiring resources and capabilities in order to prosper. Journal of Management Studies, 42(1): 183-206. 


\section{APPENDIX}

\section{Sources to Study the Patterns of State Ownership in Emerging Markets}

\begin{tabular}{|c|c|}
\hline Country & Source \\
\hline Brazil & $\begin{array}{l}\text {-Data on the number of majority- and minority-owned companies (for the federal } \\
\text { government only), and the share of SOE output to GDP comes from "Estado Ltda." Época, } \\
\text { November 6, 2011. } \\
\text {-The number of SOEs listed and their importance relative to stock market capitalization are } \\
\text { based on our calculations and consider only the largest } 100 \text { companies. All data from } \\
\text { Capital IQ. }\end{array}$ \\
\hline China & $\begin{array}{l}\text {-Share of SOE output to GDP from OECD, "State-Owned Enterprises in China: Reviewing } \\
\text { the Evidence." Paris: OECD, January 2009, p. } 6 . \\
\text {-Szamosszegi, Andrew and Cole Kyle. "An Analysis of State-Owned Enterprises and State } \\
\text { Capitalism in China." Document prepared by Capital Trade, Inc. for the U.S.-China } \\
\text { Economic and Security Review Commission, Washington D.C., } 2011 \text {. } \\
\text {-The number of SOEs listed and their importance relative to stock market capitalization also } \\
\text { come from the OECD study, p. 16, and are based on data from } 2004 \text {. }\end{array}$ \\
\hline Egypt & $\begin{array}{l}\text { - The number of SOEs is calculating by subtracting the number of privatized, leased and } \\
\text { liquidated firms from the total number of companies under government control when the } \\
\text { privatization program started in 1991. Mohammed Omran, "Ownership Structure: Trends } \\
\text { and Changes Following Privatisation in Egypt." Power point presented at the OECD Second } \\
\text { Meeting of Working Group } 5 \text { on Corporate Governance, Rabat, September 2005, available at } \\
\text { http://www.oecd.org/document/50/0,3746,en_34645207_34645863_35395890_1_1_1_1,00.h } \\
\text { tml } \\
\text {-The number of minority-owned companies (calculated using the ownership share of state- } \\
\text { owned holding companies after privatization) from "Privatization in Egypt. Quarterly } \\
\text { Review, April-June 2002." Mimeo, Carana Corporation, 2002, available at } \\
\text { http://www1.aucegypt.edu/src/wsite1/Pdfs/Privatization\%20in\%20Egypt\%20- } \\
\text { Quarterly\%20Review.pdf }\end{array}$ \\
\hline India & $\begin{array}{l}\text {-Most data from OECD, "State Owned Enterprises in India: Reviewing the Evidence." Paris: } \\
\text { OECD, January 29, } 2009 . \\
\text {-The number of SOEs listed and their importance relative to stock market capitalization are } \\
\text { based on our calculations and consider only the largest } 100 \text { companies. Data for 2009. All } \\
\text { data from Capital IQ. } \\
\text {-Data on state level public enterprises from India. Department of Public Enterprises. } \\
\text { "National Survey on State Level Public Enterprises (2006-2007)," 2007, available at } \\
\text { http:/ / dpe.nic.in/ newgl/SLPErep0607.pdf } \\
\text {-Minority-owned companies correspond to the number of firms in which the Life Insurance } \\
\text { Corporation of India (LIC), a majority-owned SOE, holds minority positions. Data on } \\
\text { holdings from LIC from Bloomberg, www.bloomberg.com, accessed on January 10, } 2012 .\end{array}$ \\
\hline Indonesia & $\begin{array}{l}\text {-Number of SOEs and minority-owned SOEs come from Andriati Fitriningrum, "Indonesia } \\
\text { Experiences in Managing the State Companies," Power point presentation at the OECD- } \\
\text { Asian Roundtable on Corporate Governance of State-Owned Enterprises, Singapore, May, } \\
\text { 2006, available at http://dpe.nic.in/newgl/SLPErep0607.pdf } \\
\text { http://www.oecd.org/dataoecd/61/22/37339611.pdf } \\
\text {-Listed SOEs to Stock market capitalization from Rajasa, Hatta. "State of Indonesian State } \\
\text { Owned Enterprises," Soverign Wealth Fund Institute web site, August, 2011, available at } \\
\text { http://www.swfinstitute.org/swf-news/state-of-indonesian-state-owned-enterprises/ }\end{array}$ \\
\hline Mexico & $\begin{array}{l}\text {-Data for Mexico comes from Kikeri, Sunita and Kolo, Aishetu Fatima, Privatization: Trends } \\
\text { and Recent Developments (November 2005). World Bank Policy Research Working Paper }\end{array}$ \\
\hline
\end{tabular}




\begin{tabular}{|c|c|}
\hline \multirow[b]{2}{*}{ Malaysia } & vailable at SSRN: http://ssrn.com/abstract $=849344$ \\
\hline & $\begin{array}{l}\text {-Data from Khazanah Nasional. "Seventh Khazanah Annual Review," } 18 \text { January 2011, } \\
\text { power point available at } \\
\text { http:// /www.khazanah.com.my/docs/30June2011_investment_structure.pdf, accessed } \\
\text { February 10, 2012. }\end{array}$ \\
\hline \multirow[t]{2}{*}{ Russia } & $\begin{array}{l}\text {-Number of SOEs, number of SOEs listed and percentage of market capitalization from } \\
\text { Carsten Sprenger. "State-Owned Enterprises in Russia," PowerPoint presentation at the } \\
\text { OECD Roundtable on Corporate Governance of SOEs, Moscow, October, 2008. Traded } \\
\text { companies exclude minority-owned firms. }\end{array}$ \\
\hline & $\begin{array}{l}\text {-The number of federal and municipal SOEs and minority-owned SOEs come from Carsten } \\
\text { Sprenger, "State Ownership in the Russian Economy: Its Magnitude, Structure and } \\
\text { Governance Problems." Mimeo Higher School of Economics, Moscow, February 2010, pp. 5- } \\
\text { 8. The number of majority- and minority-owned firms is underestimated as it only accounts } \\
\text { for direct ownership stakes, i.e., it does take into account ownership stakes of companies } \\
\text { that are, in turn, controlled by the Russian government. The number of state/local firms } \\
\text { includes only municipal companies. }\end{array}$ \\
\hline $\begin{array}{l}\text { South } \\
\text { Africa }\end{array}$ & $\begin{array}{l}\text { Report "An analysis of the financial performance of state owned enterprises," available at } \\
\text { www.info.gov.za/view/DownloadFileAction?id=95671, accessed on March 12, } 2012 .\end{array}$ \\
\hline Thailand & $\begin{array}{l}\text {-SOE output to GDP estimated using net income of the Thai SOEs and GDP for } 2004 \text {. SOE } \\
\text { data from Ruangrong, Pallapa. “ARGC Task Force on Corporate Governance of SOEs: The } \\
\text { Case of Thailand." Power point presentation, May 20, 2005, available at } \\
\text { www.oecd.org/dataoecd/14/28/34972513.ppt }\end{array}$ \\
\hline Turkey & $\begin{array}{l}\text {-Output to GDP represents net profits to GDP comes from } 2007 \text { Public Enterprise Report, p. } \\
\text { 19; the number of local level SOEs comes from p. 208. Our data on the number of federal } \\
\text { SOEs and the distinction between minority and majority-owned companies comes from the } \\
\text { lists on pp. 12, 189-190, 201, and 248-250. For our counts we exclude financial firms such as } \\
\text { banks or leasing and factoring companies owned by the Savings Deposit Insurance Fund } \\
\text { (known as TMSF). The number of minority firms refers to those controlled by the federal } \\
\text { government, so out of } 141 \text { federal SOEs, } 67 \text { are minority owned. All data from Republic of } \\
\text { Turkey. Directorate General of State Owned Enterprises. } 2007 \text { Public Enterprises Report, } \\
\text { august 2008, available at } \\
\text { http://www.treasury.gov.tr/irj/go/km/docs/documents/Treasury\%20Web/Research\&D } \\
\text { ata... } \\
\text {../Reports/State\%20Owned\%20Enterprises\%20Reports/2007_Public_Enterprises_Report.p } \\
\text { df }\end{array}$ \\
\hline Vietnam & $\begin{array}{l}\text {-The number of minority-owned companies represents the "Joint stock Co. with capital of } \\
\text { State" category from Vietnam. General Statistics Office, Statistical Yearbook of Vietnam 2010, } \\
\text { p. 181, available at } \\
\text { http:// www.gso.gov.vn/default_en.aspx?tabid=515\&idmid=5\&ItemID=11974 } \\
\text {-Data on the number of SOEs and their output to GDP from the General Statistics Office of } \\
\text { Vietnam's web page and, available at http:// www.gso.gov.vn/, accessed February 10, } 2012 .\end{array}$ \\
\hline
\end{tabular}

